\title{
mükakkir
}

Cilt:4・Sayı:8・Aralık $2017 \bullet$ s. 339-373

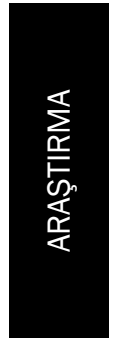

\section{MUHAMMED B. MAHMUD EL-HALVETÎ VE ŞERHU ERBAÎNE HADÎSEN KUTSIYYEN ADLI RISÂLESI}

\author{
Harun Reşit DEMiREL *
}

Öz

XV. yüzyılda Osmanlı Devleti'inde yaşamış olan Cemâlettin el-Aksarayî'nin (ö. 899/1494) doğum tarihi ve öğrenim hayatına dair bilgiler ne yazık ki yoktur. Ancak verdiği eserlerden onun bilgi ve birikim açısından müktesebâtının geniş olduğu görülmektedir. Zinciriye Medresesi'nde müderrislik yapan el-Aksarayî'nin hadis, tefsir, fıkıh, Arap dili ve tıp ilimlerinde mahir olduğu görülmektedir. Risâle fí hadis "Innallâhe Teâlâ halaka Âdeme ala sûretihîi”, Faslun fî âdâbi'z-zikr, Risâletu'r-rahîmiyye, Şerhu erbaîne hadisen kutsiyyen ve Kırk Hadis onun önemli eserlerindendir. Biz bu çalışmamızda onun hadis ilmine dair Kırk Hadis adı altında telif etmiş olduğu ve hâlen yazma eser olarak kütüphanelerimizde yer alan ve tasavvufi bir üslupla şerh ettiği Şerhu erbaîne hadisen kutsiyyen isimli eserinde yer verdiği hadislerin tahricini yapıp eserindeki metodunu inceleyerek onun ilmi kişiliğini ortaya koymaya çalışacağız.

Anahtar Kelimeler: Muhammed b. Mahmud el-Aksarayî, Hadis, Kırk Hadis, Kudsî Hadis, Şerh.

\section{Muhammed b. Mahmud Jamal al-Din al-Halwatî and His Manuscript Titled The annotation of forty hadith qudsy Abstract}

We don't unfortunately have information about the birth and education of Jamal alDin Aksarayi who lived in the XV century in the Ottoman State. However, the works shows that he was a very knowledgeable person. Al Aksarayi, who worked as a mudarris in Zinciriyye Madrasah, was capable of hadith, interpretation, jurisprudence, Arabic language and medicine. He has some works as: Risâle fî Hadiths "Innallāha Taālā khalaka âdama alā suretihi”, Risāletu'r-Rahīmiyye, Sharh Forty Hadīths, Forthy

* Doç. Dr., Aksaray Üniversitesi, İslami İlimler Fakültesi, Temel İslam Bilimleri Bölümü, Hadis Anabilim Dalı, demirelhresit@hotmail.com, ORCID iD: https://orcid.org/0000-0002-6831-8934. 
Hadith. Aksarayi's work titled Forty Hadith and interpreted by him with a mystical method and currently located as a manuscript in libraries will be studied in this article. And we will try to demonstrate his scientific personality by showing the sources of hadiths which he used and examining his method.

Keywords: Muhammed b. Mahmud Camal al-dīn al-Aksarayī, Hadith, Forthy Hadith, Divine Hadith, Annotation.

\section{GiRiş}

Çalışmamıza önce genel olarak kırk hadis türü ve edebiyatı ve Muhammed b. Mahmûd el-Aksarayî'nin hayatına kısaca değindikten sonra kudsî hadislere dair telif etmiş olduğu eseri ve metodu üzerinde duracağız.

Kırk hadisle alâkalı çalışmaların II. (VIII) asrın sonlarına doğru ortaya çıktığı ve bu sahada ilk eser veren kişinin Abdullah b. el-Mübârek (ö. 181/797) olduğu bilinmektedir. Kırk hadise dair çalışmalar içerisinde Nevevî'nin (ö. 676/1278) çalışması, diğer çalışmalara nasip olmayan bir şöhrete kavuşmuştur. Âlimlerin bu sahada oldukça fazla eser vermelerinin sebebi, Muhammed b. Mahmûd el-Aksarayî'nin de dikkat çektiği gibi, Resûl-i Ekrem'den (s.a.v.) nakledilen “Ümmetimden kim kırk hadis ezberlerse kıyamette fakîh olarak diriltilir" ${ }^{1}$ hadisidir.

Üzerinde çalıştığımız kudsî hadis mecmuasının hangi el-Aksarayî'ye ait olduğu tartışmalıdır. Problemin müellif isimlerinin kaydından kaynaklandığını düşünmekteyiz. Elimizdeki nüshada müellif ismi Muhammed b. Mahmûd Cemâlü'l-mille ve'd-din el-Aksarayî şeklinde kaydedilmiştir. Kayıtlarda bu farklılık olsa da bu eserlerin ortak noktası, eserin yazılış zamanının“Sultan Bâyezid b. Muhammed” dönemi olarak verilmesidir. Başka bir ifade ile eser II. Bâyezid (ö. 918/1512) zamanında yazıımıştır. Hâlbuki Cemâleddîn el-Aksarayî, Murat Hüdevendigar (ö. 791/1389) zamanında yaşamıştır. Bundan dolayı tespit edebildiğimiz kırk hadislerin Cemâl el-Halvetî'ye ait olması gerekmektedir. Yine Şerhu hadisi innallâhe halaka Âdem'e alâ sûretihi isimli eserin de Cemâleddin el-Aksarayî̀ye değil, Cemâl el-Halvetî’ye ait olduğunu düşünmekteyiz. Zira üslûb tamamen el-Halvetî'nin üslûbudur. Bu eserin iki nüshasında da Muhammed b. Mahmûd b. Cemâlü'l-mille ve'd-din el-Aksarayî ismi yer almaktadır. “Cemâlü'l-mille ve'd-din el-Aksarayî̀" nisbesinin bibliyograf Bursalı Mehmet Tahir Efendi’yi (ö. 1344/1925) ve Bağdatıı İsmail Paşa’yı (ö. 1339/1920) yanıltmış olmaIıdır.

1 Rivayetin birçok tariki olmasına rağmen hiçbiri sahih değildir. Darekutnî hadisin "zayıf" olduğunu bildirmiş, Nevevî de zayıflı̆̆ı konusunda ittifak olduğunu ifade etmiştir. Bk. Darekutnî, Ebu'l-Hasen Ali b. Ömer b. Ahmed b. Mehdî; el-ilelu'l-vâride fi ehadisi'n-nebeviyye, thk. Zeminullah es-Silefî, Daru Tayyibe, Riyad 1424/2003, VI, 33; Aclunî, Keşfu'l-hafa ve müzili'l-ilbâs amma iştehere mine'l-ehâdis alâ elsineti'n-nâs, Dâru Ihyai Turasi'I-Arabî, Kahire 1351, II, 220 (2463); Elbanî ise hadis hakkında "mevzu" der. bk. Silsiletu'l-ehâdisi'd-daife ve'l-mevdûa ve eseruha's-seyyii fi'l-Ümme, Dâru'l-meârif, Riyad 2002, X, 97 (4589). 
Kullanmış olduğumuz nüsha ve çalışma metodumuza gelince Şerhu Erbaîne Hadisen Kudsiyyen adlı eserin telif edildiği dönemin, Sultan Bâyezid b. Muhammed dönemi olduğunu görmekteyiz. Bir mecmua içerisinde iki eserden oluşan eser, Süleymaniye Kütüphanesi Esat Efendi 314/1'de kayıtlıdır. Mecmuadaki bir diğer eser ise el-Kelimetü li tuhfeti bi esrâri'l-besmele isimli risâledir. Eserin istinsah tarihi cemâziyelevvelin sonlarına doğru, cumartesi günü öğlen saatlerinde 1026/1617 olarak belirtilmiştir. Müstensihi ise Mustafa b. Ömer'dir.2 Çalışmamızı Esat Efendi nüshasından yararlanarak yaptık. Esas aldığımız nüsha dışındaki farklı iki nüshayı da gördüğümümüzü belirtmek isteriz. Gayemiz bir tahkik çalışması olmayıp sadece el-Aksarayî̀nin şerh metodunu ortaya koymaktır. Tahkik çalışması zaten yüksek lisans tezi olarak çalışılmıştır. ${ }^{3}$ Ancak söz konusu tezde sadece üç nüsha üzerinde durulmuş, diğer nüshaların dikkate alınmadığı görülmüştür.

Makalede öncelikle okuyucu tarafından daha iyi anlaşılması için eserde yer alan hadisleri tercüme ettik. Daha sonra hadislerin hangi eserlerde yer aldığını dipnotlarda gösterdik. Zira bu, değerlendirme ve sonuç bölümü için önem arz etmektedir. Hadis Kütüb-i Sitte gibi asıl kaynaklarda yer alıyorsa bunları vermekle yetindik, şayet onlarda yer almıyorsa tâli kaynaklara müracaat ettik. Bulabildiklerimize işaret ettik, bulamadıklarımıza ise "kaynaklarda ulaşamadık" veya benzeri ifadelerle bu duruma dikkat çektik. Müellif, hadisleri verirken senetleri vermediği gibi birçoğunda ilk ravileri de zikretmemiştir. Biz bu eksikliği gidermek için hadislerin râvilerini zikrederek verdik. Çalışmamızın son kısmında Muhammed b. Mahmûd el-Aksarayî'nin eserindeki şerh metodu üzerinde durup bunu değerlendirdik.

Bu kısa bilgiden sonra müellifimizin yaşadığı asra bakabiliriz.

\section{YAŞADIĞI ASIR}

Muhammed b. Mahmud el-Aksarayî (ö. 899/1494) XV. yüzyılda yaşamıştır. Onu daha yakından tanıyabilmek için yaşadığı asra göz atmamız yerinde olacaktır.

\subsection{Siyasî durum}

XV. yüzyılın başından itibaren Osmanlı Devleti, Anadolu'da siyasî birliğini sağlamıştır. Ne var ki 1402 yılında Timur'la (ö. 808/1405) yapılan Ankara Savaşı'ında Yıldırım Bâyazid'in (ö. 806/1403) yenilmesiyle birlikte Anadolu'nun siyasî birliği yine bozulmuş, on yıl boyunca Osmanlı Devleti fetret dönemi yaşamış, Mehmed Çelebi (ö. 824/1421), Musa Çelebi (ö. 816/1413), İsâ Çelebi (ö. 809/1406) ve Süleyman Çelebi (ö. 814/1411) arasında saltanat kavgaları yaşanmıştır. ${ }^{4}$

2 Diğer nüshalar için bk. Amasya Beyazıt İI Halk Kütüphanesi, nu: 873; Manisa İ Halk Kütüphanesi nu: 2963; Manisa Zeynelzâde, nu: 1509.

3 Kencik, Ali Rıza, Cemalettin Aksarâyî Ve Ona Nispet Edilen "Erbaun Hadisen” Adlı Eserin Tahkiki, Basılmamış Yüksek Lisans tezi, Selçuk Ünversitesi Sosyal Bililimler Enstitüsü, Konya, 2009,

4 Uzunçarşılı, İsmail Hakkı, Büyük Osmanlı Tarihi, yy. ty., II, 44. 
Fatih Sultan Mehmed'in (II. Mehmed) 3 Mayıs 1481'de vefatından5 sonra, II. Bâyezid (ö. 918/1512) tahta geçmiştir. II. Bâyezid, bir yandan kardeşi Cem Sultan'la (ö. 900/1495) mücadele ederken bir yandan da Kili6 ve Akkirman7 (1484) gibi yerler fethedilmiş, 1495'de Boğdan8 hâkimiyet altına alınmış ve 1498'de İnebahtı Savaşı kazanıımıştır. ${ }^{10}$

\section{2. İ}

Osmanlıda ilk medrese, Orhan Gazi (ö. 761/1360) tarafından 1331 yılında İznik'te kurulmuştur. ${ }^{11}$ XIV. yüzyılın sonlarında İznik Medresesi birinci dereceyi kaybetmiş ve Bursa medreseleri öne geçmiştir. XV. yüzyılın ilk çeyreğinden itibaren Edirne başkent olduktan sonra Bursa medreseleri de tâli duruma düşmüştür. II. Murad'ın (ö. 855/1451) Edirne'de yaptırmış olduğu camii, imarethâne, muallimhâane, misafirhâne ve mevlevîhaneden başka yaptırmış olduğu "yüz akçe yevmiyeli medrese" ve "elli akçe yevmiyeli dâru'l-hadis" medresesi ilk sırayı almıştır. Edirne'deki medreseler Fatih'in İstanbul'da yaptırdığı Sahn-ı Semân medreselerine kadar ilk sıradaki yerini muhafaza etmiştir. ${ }^{12}$

\section{MÜELLIFIN HAYATI}

Tam adı, Ebu'l-Fuyûzât Muhammed b. Hamîduddin b. Mahmûd b. Muhammed b. Cemâleddin el-Aksarayî'diri3 (ö.1494) Ancak el-Aksarayî'nin adı, muhtelif kaynaklarda farklı şekillerde geçmektedir. ${ }^{14}$ isimlerde farklılık olsa da ismi üzerinde çalıştığımız eserde Muhammed b. Mahmûd Cemâlü'l-Mille ve'd-Dîn el-Aksarayî olarak yer

5 Uzunçarşılı, Büyük Osmanlı Tarihi, II, 143-44.

6 Bugün Ukrayna Cumhuriyeti sınırları içinde bulunan tarihî kale ve şehir. Romence'de Chilia (Kilya) adıyla anılır. Tuna nehrinin denize dökülürken oluşturduğu üç koldan biri olan en kuzeydeki Kili kolunun sol kıyısında bulunmaktadır. Bk. Maxim, Mihai, “Kili”, DiA, Ankara 2002, XXVI, 1-3.

7 Ukrayna Sovyet Sosyalist Cumhuriyeti'nin Odesa eyaletinde bir şehir. Dinyester nehrinin Karadeniz'e döküldüğü yerde, önü sonradan kapanarak kıyı gölü haline gelen bir körfezin sağ kenarında bulunmaktadır. Bk. Bilge, Mustafa L., “Akkirman”, DiA, İstanbul 1989, II, 269-270.

8 Romanya'nın Moldavya bölgesine Osmanlı döneminde verilen ad. Bk. Özcan, Abdülkadir, “Boğdan”, DiA, İstanbul 1992, VI, 269-271.

9 Yunanistan'da Korint körfezinde Navpaktos kasabasının Osmanlılar dönemindeki adı. Epakto, Lepanto adlarıyla da anılan kasaba Korint körfezi girişinde, Mora yarımadasındaki Patras (Balyabadra) şehrinin karşısındaki Yunan ana karası kıyısında yer almakta olup bugün 8000 nüfuslu küçük bir yerleşim yeri durumundadır. Bk. Kiel, Machiel, “İnebahtı”, DiA, İstanbul 2000, XXII, 285-287.

10 Uzunçarşılı, Büyük Osmanlı Tarihi, II, 217.

11 Osmanlıda medreseler ve okutulan dersler için bk: Hızlı, Mefail, “Osmanlı Medreselerinde Okutulan Dersler ve Eserler”, Uludağ Ünv. İlahiyat Fakültesi Dergisi, Bursa, XVII/I (2008): 26.

12 Uzunçarşılı, Büyük Osmanlı Tarihi, I, s.523.

13 Tayşi, Mehmed Serhan; “Cemâl-î Halvetî”, Türkiye Diyanet Vakfı İslam Ansiklopedisi, İstanbul 1993, VII, 302; Öngören Reşat, Osmanlılarda Tasavvuf Anadolu'da Sûfîler Devlet ve Ulema (XVI Yüzyıl); İstanbul 2000, s.43.

14 Bk. Cemal Halvetî ve Çelebi Halife isimlendirmesi için bk. Abdurrahman Câmiî, Nefahâtu'l-üns min hadarâti'l-kuds, çev. Lâmiî Çelebi, İstanbul 1980, s.579; Taşköprüzade Ebu'l-Hayr i̇sâmuddin Ahmed Efendi, eş-Şekâikun-numâniye fi ulemâi'd-devleti'l-osmâniyye, thk. Ahmet Sübhi Furat, İstanbul Üniversitesi Edebiyat Fakültesi Basımevi, I. bs., İstanbul 1985, s. 267; Bursalı Mehmet Tahir, Osmanlı Müellifleri, Matbaa-i Amire, İstanbul 1333, I, 51; Bilmen Ömer Nasuhi, Büyük Tefsir Tarihi Tabakatu'l müfessi- 
almaktadır. Kaynaklarda ailesi hakkında fazla bir bilginin yer almadığı müellif, Cemâleddin el-Aksarayî'nin soyundan gelmektedir. el-Aksarayî nesep yönünden Fahruddin Râzî̀ye ulaşmaktadır. Doğum tarihi ve nerede doğduğu hakkında kesin bir bilgi yoktur. Kimileri aslen Karamanlı olup Amasya'da doğduğunu ifade ederken ${ }^{15}$ kimi müellifler de onun Aksaray doğumlu olduğunu ileri sürmüşlerdir. ${ }^{16}$

Bununla birlikte aslen Aksaraylı olan Cemâlî ailesinin neredeyse tüm fertlerinin Amasya'da yollarının kesiştiğini görmekteyiz. Cemâlîler için bu şehrin önemi, büyük dedesini Cemâleddin el-Aksarayî'den kaynaklandığı düşünülmektedir. Dedesinin Aksaray'a dönmesinden sonra Amasya, ailenin diğer fertleri için bilinen bir yerdir.

Amasya'nın cazibe merkezi olması, şehzadeler şehri olarak tanınmasının yanı sıra ilmî hayatta medreselerinin önemli bir yeri olmasından kaynaklanmaktadır. Özellikle de şehzadeliği Amasya'da geçen II. Bâyezid'in ilme ve ulemâya önem vermesi, şehri cazibe merkezi haline getirmiştir. ${ }^{17}$ Müellifimiz Cemâl el-Aksarayî ve diğer Cemâlîler II. Bâyezid'in padişah olmasından sonra onun daveti üzerine 1485 yılında İstanbul'a gelmişlerdir. ${ }^{18}$ Cemâl el-Aksarayî, İstanbul'a gelince Koca Mustafa Paşa(ö. 918/1512) tarafından kendisi için yaptırılan dergâhta postnişin olarak irşad vazifesini devam ettirmiştir. ${ }^{19}$ Kendisi Halvetîliğin İstanbul'daki ilk önemli temsilcisidir. XV. yüzyılda Halvetîlik, Kadirîlik ve Mevlevîlik tarikatları Osmanlı'da yayılmaya başlamıştır.

Cemâlî ailesi, II. Bâyezid, Yavuz (926/1520) ve Kanuni (974/1566) dönemlerinde topluma önemli katkılarda bulunmuşlar ve devlet adamı olarak hizmet etmişlerdir. Cemal el-Halvetî tasavvuf alanında, oğlu Pîrî Mehmed Paşa (940/1533) idare

rin, Bilmen Yayınevi, İstanbul 1974, II, 617; Ateş Süleyman, i̇şari Tefsir Okulu, Ankara Üniversitesi İlahiyat Fakültesi, Ankara 1974, s. 224; Tayşi, "Cemâl-î Halvetî", s. 302; Muhammed Cemâlî ismi için: Mehmed Süreyya, Sicill-i Osmanî yahut Tezkire-i meşâhir-i osmaniyye, (The Ottoman Biography), I. bs., İstanbul 1971, IV, 105; Çelebi Halife eş-Şeyh Muhammed b. Muhammed el-Cemâlî el-Halvetî er-Rûmî ismi için bk. Bağdatılı İsmail Paşa, İdâhu'l-meknûn fi'z-zeyl alâ keşfi'z-zunûn an esâmii'l-kutub ve'l-funûn, Milli Eğitim Bakanlığı, Ankara 1971, II, 510; Cemâleddin Karamânî ve Çelebi Karamânî için: Camiî, Nefahatu'I-Üns Min Hadarati'I-Kuds, çev. Abdulkadir Akçiçek, Huzur Yayınevi, 2013, s. 579; Ahmed Rıfat Efendi (Yaglıkçızâde), Lügât-ı tarihiyye ve coğrafiyye, Mahmut Bey Matbaası, İstanbul 1299, III, 44; Çelebi Halife Muhammed Cemâleddin Halvetî için bk. Rıfat Efendi, Lügât-ı tarihiyye, Mahmut Bey Matbaası, İstanbul 1895 ,III, 44; Muhammed b. Muhammed el-Cemâlî el-Bekrî el-Halvetî er-Rumî için: Kehhâle Ömer Rıza, Mu'cemi'l-müellifîn (Terâcimu Musannifi'l-kutubi'l-arabiyye ), Daru'l-kütübi'l-ilmiyye, I. bs., Beyrut 1957, XI, 203; İsmail b. Abdillah er-Rûmî es-Sûfî el-Halvetî Cemâleddin ismi için: Zirikli Hayreddin, el-A'lâm kâmûsu terâcimi li eşheri'r-ricâl ve'n-nisâ, Daru'l-ilim, II. bs., Kahire 1976, I, 315.

15 Mehmed Tahir, Osmanlı Müellifleri, I, 51; Bilmen, Büyük Tefsir Tarihi, II, 617; Ateş, İşari Tefsir Okulu, s. 224.

16 Yusuf b. Yakub, Menâkıbı şerif ve tarikatname-i piran ve meşayihi tarikat-ı aliye-i halvetiyye, İstanbul 1290, s.16; Tayşi; “Cemâl-î Halvetî”, s. 302.

17 Hüseyin Hüsameddin, Amasya Tarihi, Hikmet Matbaası, I. bs., İstanbul 1927, III, 22.

18 Küçükdağ Yusuf, II. Bayezid Yavuz ve Kanunî Devirlerinde Cemalî Ailesi, PRS Perek Yayıncılık, İstanbul 1995, s. 166.

19 Mehmet Tahir, Osmanlı Müellifleri, I, 151; Ateş; Işari Tefsir Okulu, s. 224; Tayşi, “Cemal Halveti”, s. 302. 
alanında ve amcazadesi Zenbilli Ali Efendi (932/1526) ilmi alanda temâyüz etmişler, döneminin sultanlarına ve devlete yön vermişlerdir. ${ }^{20}$

Muhammed b. Mahmûd el-Aksarayî'nin vefat tarihi hakkında kesin bir bilgi bulunmamaktadır. O, padişah II. Bâyezid (1481-1512) tarafından veba hastalığına yakalananlara dua etmesi için kırk dervişiyle birlikte hacca gönderilmiş, ancak yolda Tebük korusu21 denilen mevkiide, 899/1493-94 yılında vefat etmiş ve vasiyeti üzerine hacıların yol güzergâhı üzerine defnolunmuştur. ${ }^{22}$

\section{ESERLERI}

Müellifimiz Osmanlı döneminde çok eser veren sûfîlerden birisidir. Eserlerinin sayısı yirmi23 veya yirmi bir24 civarındadır. Bu eserlerden bazıları şunlardır:

a. er-Risâletü'l-kevseriyye fî beyâni te'vîli esrâri'l-Kur'ân

b. Envâru'l-kulûb li talebi rü'yeti'l- mahbûb

c. Risâle fî beyâni esrâri'l-vudûi'z-zâhiriyye ve'l-ma'neviyye

d. Risâletu'r-rahîmiyye

e. Şerhu erbaîne hadîsen kudsiyyen

f. Te'vilâtu erbaîne hadîsen

g. Risâle fî hadis "İnnallâhe Teâlâ halaka Âdeme alâ sûretihi”

h. Esrâru'l-ilâhiyye

i. Faslun fî âdâbi'z-zikr.

Bibliyograf Mehmed Tahir, bizzat gördüğü bu eserler hakkında "Eserlerinden bizzat gördüğüm bilhassa Tefsir Risâlesi ile Hadis-i Erbaîn Şerhi ve Sa'd Kelime-i Imam-ı Ali Şerhi gerçekten muhakkikkâne ve ârifânedir" 25 demektedir.

Şerhu Erbaîne Hadisen Kudsiyyen isimli eserde de görüleceği gibi bu eser Cemâleddin el-Aksarayî'ye ait değil Ebu'l-Fuyûzât Muhammed b. Hamîduddin b. Mahmûd b. Muhammed b. Cemâleddin el-Aksarayî̀ye aittir. Aşağıda görüleceği gibi müellif hadisleri tamamen tasavvufi bir metotla şerh etmiştir. Halbuki Cemâleddin Aksarayî'nin tasavvufi bir yönü yoktur. Bundan dolayı mezkûr eser, kendi soyundan gelen ve Halvetî şeyhi olan Ebü'l-Fuyûzât Muhammed b. Hamîdüddin b. Mahmûd'a ait bir risâledir.

j. Şerhu erbaîne hadisen kudsiyyen

20 Küçükdağ; II. Bayezid Yavuz ve Kanunî Devirlerinde Cemalî Ailesi, s. 28.

21 Mehmed Tahir, Osmanlı Müellifleri, I, 51; Tayși; “Cemal Halveti”, s. 302.

22 Mehmed Tahir, Osmanlı Müellifleri, I, 51; Ateş; İşari Tefsir Okulu, s. 224. Vefat tarihi hakkında farklı görüşler yer almaktadır. Bilmen; Büyük Tefsir Tarihi, II, 617; Kehhale, Mu'cemi'l-müellifin, XI, 203.

23 Tayși, "Cemâl-î Halvetî", ss. 302, 303.

24 Mehmed Tahir, Osmanlı Müellifleri, I, 52.

${ }^{25}$ Mehmed Tahir, Osmanlı Müellifleri, I, 52. 
el-Aksarayî'nin çalışmamaza konu olan eseridir. Girişte de ifade ettiğimizden aynı bilgileri tekrar emeyeceğiz. Şu kadarını ifade edelim ki el-Aksarayî, şerhinde “hadis-i kudsiye dair 40 hadis ve âsâr'ı cem edeceğini ve bu hadisleri tasavvufi bir metotla tevil ederek hassas bir şekilde şerh yapacağını" ifade etmektedir. ${ }^{26} 0$, amacını ve metodunu “Allah'ın izniyle ulemâ ve fudelâ'nın metotlarını meslek edinerek 40 hadis sahasında eser telif eden âriflere ve evliyâya benzemek için hadislerin esrarını beyan ettim" diyerek açıklamaktadır.

\section{KIRK KUDSÎ HADIS TERCÜMESI}

Aşağıda Şerhu Erbaîne Hadisen Kudsiyyen adlı eserde yer verilen kudsî hadislerin metinlerini kaydedip tercümesini verecek ve hadislerin tahricini yapacağı. Kaynağını tespit edemediğimiz hadislere de dipnotlarda işaret edeceğiz.

\section{[2a] Hadis no: 1}

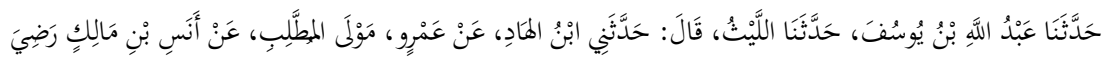

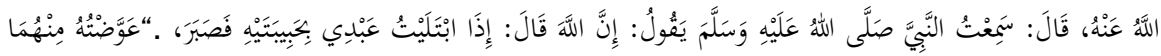

"Kulumu iki sevdiği şeyle imtihan ettiğimde o sabrederse, sabrettiği bu iki şey karşılığında ona cenneti veririm." 27

Müellif, hadisin râvisi olarak Enes b. Mâlik'i vermiştir. Ayrıca bu rivayeti Buhârî'den aldığını belirtmiştir.

[2b] Hadis no: 2

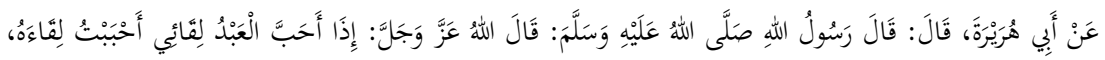

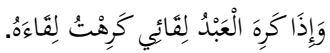

“Kulum bana kavuşmayı sevdiğinde ben de onun kavuşmasını severim, şayet bana kavuşmayı sevmezse onun kavuşmasından hoşlanmam." 28

${ }^{26}$ Aksarayî, Şerhu erbaîne hadisen kutsiyyen, Süleymaniye Kütüphanesi Esat Efendi Bölümü nu: 314, 2/a.

27 Buhârî, Muhammed b. İsmail el-Cu'fi, el-Camiu's-sahîh, thk. Muhammed Zuheyr b. Nâsır en-Nâsır, Daru Tavki'n-Necat, 1422, I. bs., VII, 116 (5653); Ahmed b. Hanbel Ebû Abdillah eş-Şeybânî, Müsned, thk. Şuayb Arnavud vd., Kontrol Abdullah b. Abdilmuhsin Türkî, Müssesetü'r-Risâle, I. bs., 2001, XIX, 449 (12467) (Hadis sahîhtir.); Ebû Ya'la, Ahmed b. Ali b. el-Müsennâ b. Yahya b. İsa b. Hilâl et-Temimî elMevsılî, Müsned-i Ebi Ya'lâ, thk. Hüseyin Selim Esed, Dâru'l-Me'mûn li't-Türâs, I. bs., Dımeşk 1984/1404, XI, 225 (6339). Muhakkik isnadının hasen olduğunu söylemektedir; Taberâni, Süleyman b. Ahmed b. Eyub el-Lahmî eş-Şamî, el-Mu'cemu'l-evsât, thk. Târık b. Ivâdillah Abdulmuhsin b. İbrahim, Dâru'l-Harameyn, Kahire, 1415, I, 86 (250); Beyhakî, Ahmed b. el-Hüseyin b. Ali b. Musa el-Hüsrevverdî el-Horasanî Ebû Bekr, es-Sünenü'l-kübrâ, thk. Muhammed Abdulkadir Atâ, Mektebetu Dâru'l-Bâz, III. bs., Beyrut 2003/1424, III, 525 (6552).

28 Ahmed b. Hanbel, Müsned, XV, 510 (9822). Hadisin sahîh, isnadının hasen olduğunu tahkik edenler söylemiştir: Begavî, Ebû Muhammed Hüseyin b. Mesud b. Muhammed b. Ferrâ, Şerhu's-sünne, thk. Şuayb Arnavud-Muhammed Zuheyr Şaviş, Mektebetü'l-islamî, III. bs., Dımeşk- Beyrut 1983/1403, V, 262 (1448). Müellif hadisin “sahîh” olduğunu söyler: Ebû Ya‘lâ, Müsned, VI, 375 (3711). Muhakkik isnadının "sahîh” olduğunu söyler. 
Müellif hadisin sahâbî râvisi olarak Ebû Hüreyre'yi zikretmiştir.

[2b] Hadis no: 3

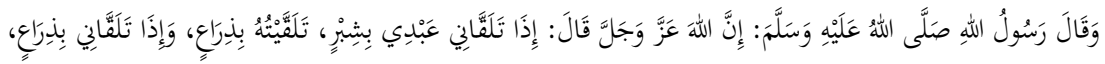

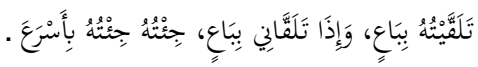

Allah Teâlâ şöyle buyurdu: "Bir kimse bana bir karış yaklaşırsa ben ona bir arşın yaklaşııım. Bir kimse bana bir arşın yaklaşırsa ben ona bir kulaç yaklaşırım. Bir kimse bana yürüyerek gelirse ben ona koşarak giderim."29

Müellif hadisin râvisi olarak Ebû Hüreyre'yi kaydetmiştir.

\section{[2b] Hadis no: 4}

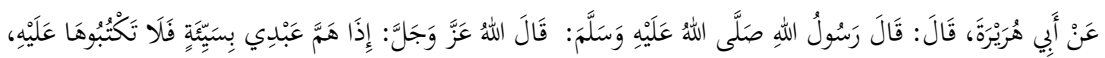

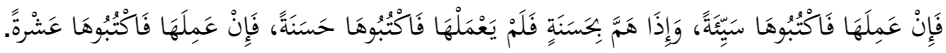

Allah Azze ve Celle şöyle buyurdu: "Şayet kulum bir günah işlemeye niyetlense ama yapmasa ona günah yazmam; şayet o günahı işlerse o günahın karşıı̆ını yazarım. Şayet güzel bir iş yapmaya niyetlense ve onu yapmasa da ona sevap yazarım. Şayet o güzel işi yaparsa ona on misli sevap yazarım." ${ }^{30}$

Müellif hadisin sahâbî râvîsi olarak Ebû Hüreyre'yi vermiş, Müslim tarafından rivayet edildiğini belirtmiştir.

[3a] Hadis no: 5

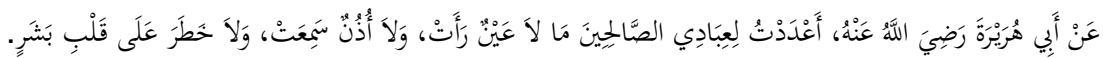

Allah Azze ve Celle şöyle buyurdu: "Salih kullarıma hiç bir gözün görmediği, hiç bir kulağın işitmediği, hiç bir beşerin kalbinin hatırlamayacağı -şeyler- hazırladım.” ${ }^{31}$

Müellif hadisin sahâbî râvîsi olarak Ebû Hüreyre'yi vermiştir.

[3a] Hadis no: 6

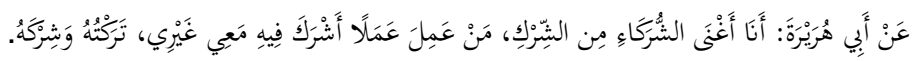

29 Müslim b. el-Haccâc el-Kuşeyrî en-Nisâbûrî, el-Müsnedü's-sahîh, thk. Muhammed Fuad Abdilbakî, Dâru İhyâi't-Türâsi'l-Arabî, Beyrut ty., IV, 2061 (2675); Ahmed . Hanbel, Müsned, XIII, 517 (8193), XXI, 418 (14013); Beğavî, Şerhu's-Sünne, V, 25 (1252).

30 Müslim, Sahîh, I, 117 (128). Bu eserlerde "seyyie" yerine “hasene" ile hadis devam etmektedir. Tirmizî, Sünen, thk: (heyet), Mustafa el-Babi, II. bs., Mısır 1975, V, 265, h. nu: 3073, (hasen-Sahîh); Bezzâr, Ebû Bekr Ahmed b. Amr b. Abdilhalik, Müsned, thk. Adil b. Sa'd, el-Ulûm ve'l-Hikem matbaası, Medine-i Münevvere, I. bs., 1988-2009, XV, 323 (8869); Beyhakî, es-Sünenü'l-kübrâ, X, 98 (11117); ỉbn Hıbbân, Muhammed b. Hıbbân el-Bustî, Sahîh, thk. Şuayb Arnavud, Müessesetü'r-risâle, I.bs., Beyrut, 1988/1408, II, 104 (380).

31 Buharî, Sahîh, IV, 118 (3244); VI, 115 (4779); VI, 116 (4780); IX, 144 (7498); Müslim, Sahîh, IV, 2174 (2824); IV, 2175 (2824); IV, 2175 (2825); Tirmizî, Sünen, V, 346 (3197); ibn Mâce, Ebû Abdillah Muhammed b. Yezîd, Sünen, thk. Muhammed Fuad Abulbâki, Dâru'I-Fikr, Kahire ty., II, 1447(4328); Humeydî, Müsned, thk. Hasen Selim Esed, Dâru's-Saka, I. bs., Dımeşk, 1996, II, 275 (1167). 
Allah-ı Tebâreke ve Teâlâ buyurdu: "Ben, bana şirk koşanların şirkinden beriyim. Her kim bir bana ortak koşarak bir iş yaparsa onu ve şirkini baş başa bırakırım." ${ }^{32}$

Müellif hadisin râvisi olarak Ebû Hüreyre'yi vermiştir.

[3a] Hadis no: 7

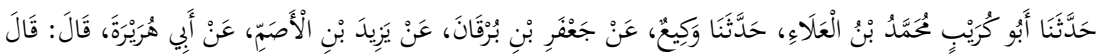

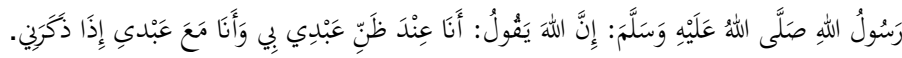

“Ben kulumun zannı üzereyim. Beni zikrettiğinde ben de onunla beraberim." 33

Müellif hadisin sahâbî râvîsi olarak Ebû Hüreyre'yi vermiştir.

[3b] Hadis no: 8

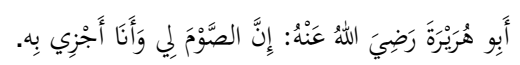

Ebû Hüreyre rivayet eder: “Oruç benim içindir. Onun karşılığını ben vereceğim. ${ }^{34}$

Görüldüğü gibi bu rivayeti ashaptan Ebû Hüreyre rivayet etmektedirler.

[3b] Hadis no: 9

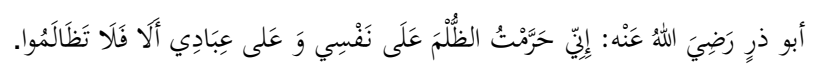

“Ben zulmü kendi nefsime ve kullarıma haram kıldım. Dikkat ediniz! Zulmetmeyiniz... "35

32 Müslim, Sahîh, IV, 2289 (2985); İbn Mâce, Sünen, II, 1405 (4202); ỉbn Huzeyme, Ebû Bekr Muhammed b. İshâk en-Nisâbûrî, Sahîh, thk. Muhammed Mustafa el-Azamî, Mektebetü'l-islamî, Il.bs., Beyrut 1992, II, 67 (938); Taberânî, el-Mucemu'l-evsât, I, 47 (130).

33 Müslim, Sahîh, IV, 2067 (2675); Tirmizî, Sünen, IV, 596 (2388); ỉbn Hıbbân, Sahîh, Müessesetü'r-Risâle,

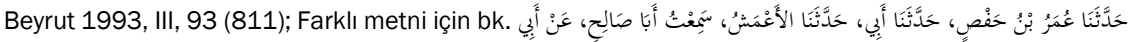

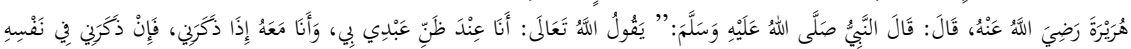

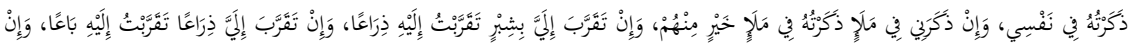

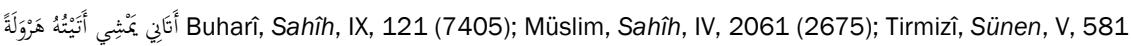
(3603); İbn Mâce, Sünen, II, 1255 (3822).

34 Müslim, Sahîh, II, 807 (1151); Ahmed, Müsned, XII, 96 (7173); İbn Ebî Şeybe, Musannef fi'l- ehâdis ve'lasâr, thk. Kemal Yusuf el-Hût, Mektebetü'r-Rüşd, Riyad 1409, II, 272 (893).

35 Beyhakî, Ahmed b. el-Hüseyin, el-Kadâ ve'l-Kader, thk.Muhammed b. Abdillah Âl-i Âmir, Mektebetu'l-

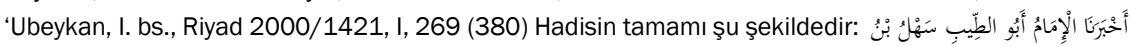

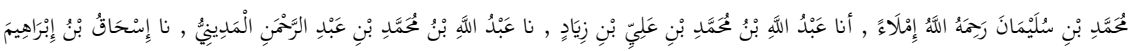

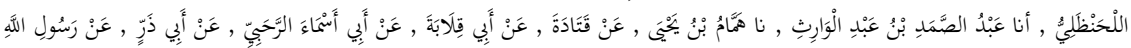

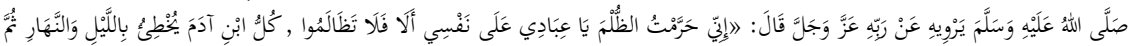

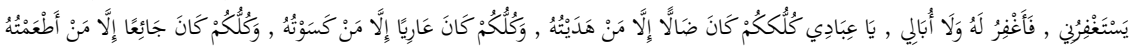

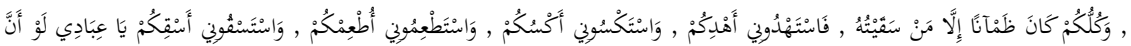

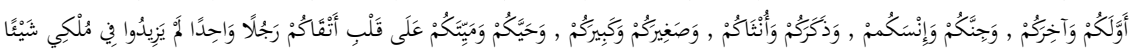

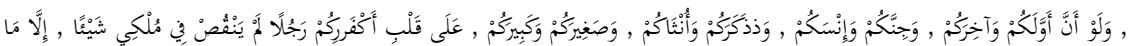


Müellif bu rivayeti uzunca bir hadisten yukarıda kaydettiğimiz kısmı alarak rivayet etmektedir. Hadis, bazı metin farklılıkları ile beraber farklı kaynaklarda da yer almaktadır. 36

Müellif hadisin sahâbî râvîsi olarak Ebû Zerr'i vermiştir.

[4a] Hadis no: 10

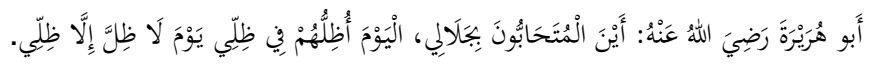

Allah (c.c.) kıyamet gününde "Celâlim için birbirlerini sevenler nerede, onları hiç bir gölgenin olmadığı bu günde kendi gölgemle gölgelendireceğim” 37 diyecek.

Müellif hadisin sahâbî râvîsi olarak Ebû Hüreyre'yi zikretmiştir.

[4a] Hadis no: 11

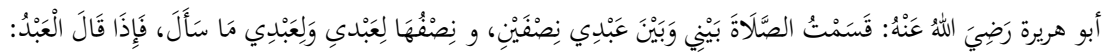

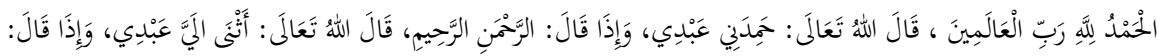

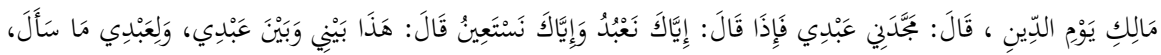

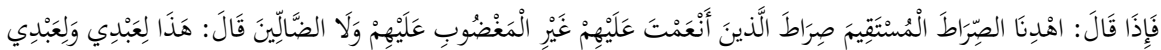

$$
\begin{aligned}
& \text { مَا سَأَلَ. }
\end{aligned}
$$

"Namazı benimle kulum arasında ikiye ayırdım. Kuluma istediği verilir. Kul

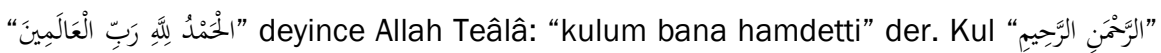

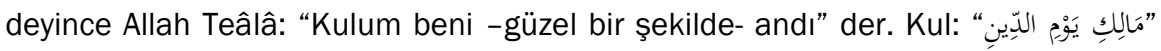

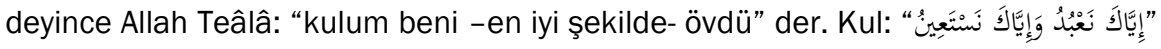
deyince Allah (c.c.): “Bu benimle kulum arasındadır. Kuluma istediği verilir.” Kul:

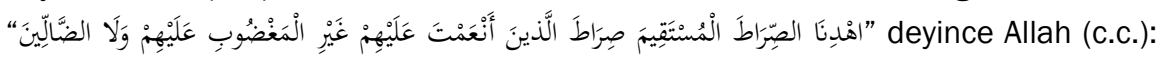
“Bu kulum içindir ve kuluma istediği verilir" buyurur. ${ }^{38}$

ايَنْعُصُ رَأَسُ الْمِخَيَطِ مِنَ الْبَحْرِ fiyye, I. bs., Beyrut 1988/1408, I, 341 (847).

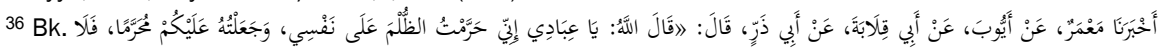

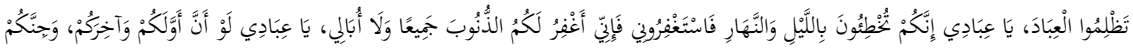

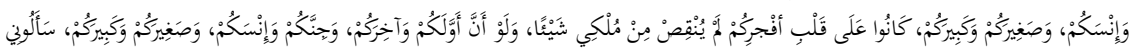

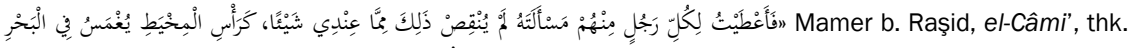
Habîbu'r-Rahmân el-Azamî, el-Mektebu'l-İslamî, II. bs., Beyrut 1403, XI, 182 (20272); Lafız farlııılarıyla birlikte benzer rivayetler için bk. Müslim, Sahih, IV, 1994 (2577); Bezzâr, Ebû Bekr Ahmed b. Amr, Müsned, IX, 441 (4053); İbn Hibbân, Sahîh, II, 385 (619); Beyhakî, Sünen, VI, 154 (11503).

${ }^{37}$ Müslim, Sahîh, IV, 1988 (2566); Malik b. Enes, Muvatta, thk. M. Fuad Abdulbakî, İstanbul, Çağrı yayınevi, 1992, II, 952 (13); Ahmed, Müsned, XII, 169 (7232); Beyhakî, Sünen, X, 393 (21067).

38 Müslim, Sahîh, I, 296 (395); I, 297 (395); Ebû Davud, Süleyman b. el-Eş'as, Sünen, thk. Muhammed Muhyiddin Abdilhamid, Dâru'l-Fikr, Beyrut ty., I, 216 (821); Tirmizî, Sünen, V, 201 (2953); Nesâî, Ebû Abdirrahman Ahmed b. Şuayb, Sünen, thk. Abdulfettah Ebû Gudde, Mektebetü'l-Matbuati'l-islamiyye, Haleb 1986/1406, II, 135 (909); İbn Mâce, Sünen, II, 1243 (3784); Mâlik b. Enes, Muvatta, I, 84 (39); Ahmed, Müsned, XII, 239 (7291). 
Müellif hadisin sahâbî râvîsi olarak Ebû Hüreyre'yi zikretmiştir.

[4a] Hadis no: 12

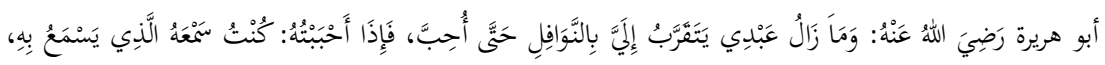

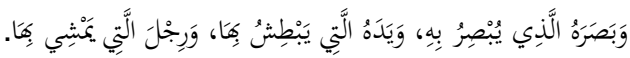

"Kulum Bana nafile ibadetlerle kendisini sevene dek ibadet eder. Onu sevdim mi de onun kulağı olur, kulum onunla işitir, gözü olur onunla görür, eli olur onunla galip gelir, ayağı olur onunla yürür." 39

Müellif, hadisin sahâbî râvîsi olarak Ebû Hüreyre'yi vermiştir. Kaynaklarda müellifin bu şekilde vermiş olduğu rivayetin metnin evvelinde ve sonunda daha farklı bilgiler de yer almaktadır.

[4b] Hadis no: 13

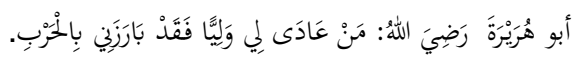

“Her kim benim veli kuluma düşman olursa, bana harp açmış olur"40

Müellif hadisin sahâbî râvîsi olarak Ebû Hüreyre'yi vermiştir.

[4b] Hadis no: 14

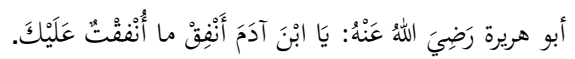

“Ey Âdemoğlu sana tasaddukta bulunduğum gibi sen de tasaddukta bulun!"41

Müellif, hadisin sahâbî râvîsi olarak Ebû Hüreyre'yi vermiştir.

[4b] Hadis no: 15

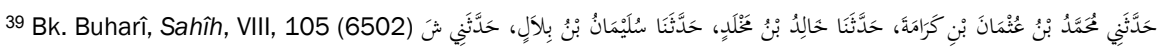

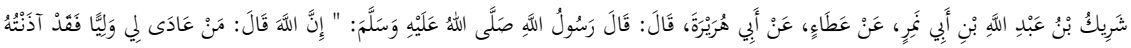

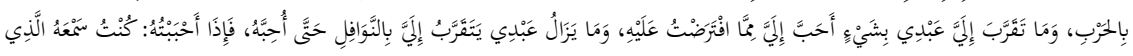

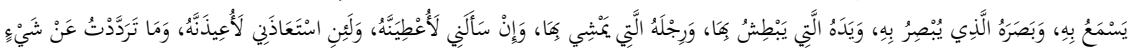

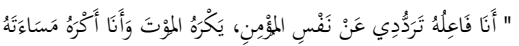

Ma'mer b. Râşid, el-Câmi', XI, 192 (20301); Ebû Davud, ez-Zühd, thk. Ebû Temîm Yâsir b. İbrahim b. Muhammed, Daru'I-Mişkât, I. bs., Halvân 1993/1414, I, 33 (5); Taberânî, el-Mucemu'l-kebir, thk. Hamdî b. Abdilmecid es-Silefí, Mektebetü'l-Ulûm, II. bs., Musul 1984, VIII, 206 (7833); Beyhakî, Sünen, III, 482 (6395); X, 370 (20980); III, 482 (6395); Beyhakî, el-Esmâ ve's-sıfât, thk. Abdullah b. Muhammed elHaşidî, Matbaatu's-Saâde, I. bs., Cidde 1993/1413, II, 447 (1029); Taberânî, el-Mucemu'l-evsât, I, 192 (609); Kudâî, Ebû Abdillah Muhammed b. Selâme, Müsnedu'ş-şihâb, Müessetü'r-Risâle, II. bs., Beyrut 1986, II, 327 (1456).

40 Bk. Buharî, Sahîh, VII, 62 (5352); Müslim, Sahîh, II, 690 (993); Ahmed, Müsned, XII, 247 (7298); Ebû Ya'la, Müsned, XI, 134 (6260).

41 Buharî'de rivayet أُنْفِق sinden kaynaklanmaktadır. Bk. Reşit Efendi, 510/a; Esat Efendi, 4/b.

Buharî, Sahîh, VII, 62 (5352); Aliyu'I-Kârî, Mirkâtul-mefâtihu'l-gayb şerhu mişkâtu'l-mesâbîh, Dâru'l-fikr, Beyrut, 2002, IV, 1319 (1862). Hadis hakkında "müttefakun aleyh" demekle beraber bu hadis Müslim'de yer almamaktadır. 


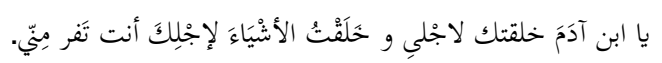

"Ey Âdemoğlu seni kendim için, eşyayı da senin için yarattım. Sen ise benden kaçıyorsun." 42

Müellif hadisin ilk râvîsini vermemiştir.

[5a] Hadis no: 16

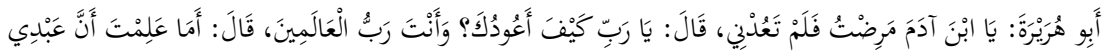

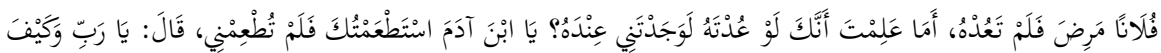

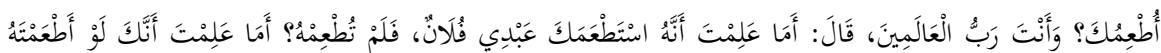

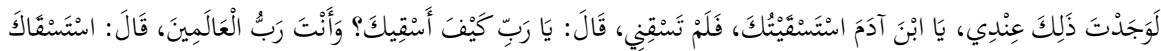

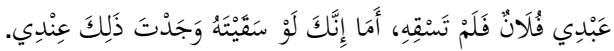

Resûlullah (s.a.v.) Allah Teâlâ'dan naklen anlatıyor:

"Allah şöyle buyurdu: "Ey Âdemoğlu hasta oldum, ziyaretime gelmedin." Âdemoğlu sordu; 'Ya Rabbi sen âlemlerin Rabbisin. Seni nası ziyaret edeyim?' Allah buyurdu; 'Bilmiyor musun? Falan kulum hasta oldu, ama sen onu ziyaret etmedin. Eğer onu ziyaret etseydin Beni yanında bulacaktın'. Allah devamla buyurdu: 'Ey Âdemoğlu, senden yemekle doyurulmamı istedim, ama sen Beni doyurmadın'. Âdemoğlu sordu: 'Yâ Rabbî seni yemekle nasıl doyurayım? Sen âlemlerin Rabbisin. Bunun üzerine Allah Teâlâ: 'Falan kulum senden yemek istedi, ama ona yedirmedin. Bilemedin mi? Ona yedirseydin Beni yanında bulacaktın' der. Allah devamla 'Ey Âdemoğlu, senden su istedim, ama vermedin'. Âdemoğlu sordu: 'Yâ Rabbî Sana nasıl su vereyim? Sen Âlemlerin Rabbisin'. Allah buyurdu: 'Falan kulum senden su istedi vermedin. Ona su verseydin Beni yanında bulacaktın. Bunu da mı anlayamadın?"43

Müellif hadisin sahâbî râvîsini zikretmemiştir.

[5b] Hadis no: 17

$$
\begin{aligned}
& \text { قال الله تعالي يا عبادي كلكم ضالٍ الا من هديته فاسهدوني أهديكم يا عبادي كلكم جايع الا من أطعمته } \\
& \text { فاستطعموني أطعمكم با عبادي كلكم عار إلا من كسوته فاستكسوني أكسكم. }
\end{aligned}
$$

Resûlullah'ın haber verdiğine göre Allah Teâlâ “Ey benim kullarım! Benim hidayete erdirdiklerim müstesna hepiniz sapıklık içeresindesiniz. Benden hidayet dileyiniz ki sizi hidayete erdireyim. Ey benim kullarım! Benim doyurduklarım hariç hepiniz

\footnotetext{
42 Rivayete ulaşamadık.

43 Müslim, Sahîh, IV, 1990 (2569); İshak b. Râhuye, Müsned, thk. Abdulgafur b. Abdilhak el-Belûşî, Mektebetü'l-Imân, I. bs., Medine, 1991/1412, I, 115 (28); İbn Hibbân, Sahîh, III, 224 (944); Beğavî, Şerhu'sSünne, V, 218 (1409); Buharî, el-Edebu'l-müfred bi't-Ta'likat, thk. Semir b. Emin ez-Zührî, Mektebetu'lMeârif, I. bs., Riyad 1998/1419, I, 266 (517).
} 
açsınız. Yemek talep ediniz ki ben de sizi doyurayım. Ey benim kullarım! Benim giydirdiklerim hariç hepiniz çıplaksınız. Benden örtünmeyi talep ediniz sizleri giydireyim." buyurmuştur. ${ }^{44}$

Müellif daha önce de yaptığı gibi uzun bir hadisin bir kısmını rivayet etmektedir. Müellif hadisin hadisin sahâbî râvîsini zikretmemiştir.

[6a] Hadis no: 18

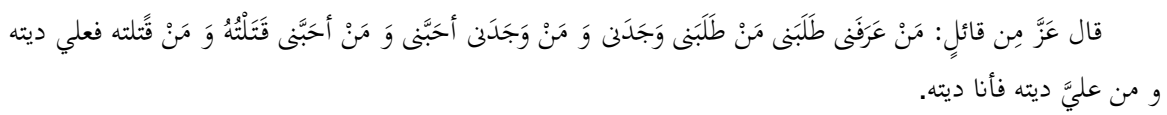

Resûlullah'ın haber verdiğine göre Allah Teâlâ “Kim beni tanırsa beni talep eder. Kim beni talep ederse beni bulur, kim beni bulursa beni sever, kim beni severse onu öldürürüm. Kimi öldürürsem onun diyeti bana aittir. Kimin diyeti de bana ait olursa, onun diyeti benimdir" buyurmuştur.

Müellifin sahâbî râvîsini vermediği bu rivayete kaynaklarda ulaşamadık.

[6a] Hadis no: 19

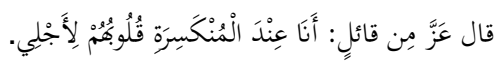

Allah Teâlâ "Ben; benim için kalpleri mahzun olan kullarımla beraberim” buyurmuştur. 45

[6a] Hadis no: 20

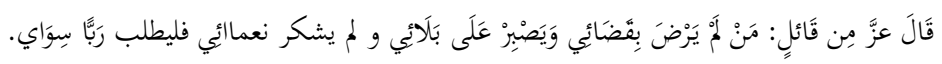

Resûlullah'ın haber verdiğine göre Allah Teâlâ: “Her kim ki kazama rıza göstermez, belalarıma da sabretmezse artık varsın kendine benden başka bir Rab arasın" buyurmuştur. 46

[6a] Hadis no: 21

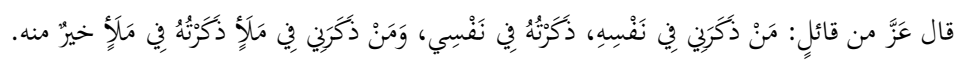

44 Lafız farklıılarıyla birlikte bk. Müslim, Sahih, IV, 1994 (25779); Tirmizî, Sünen, IV, 656 (2495); İbn Ebî Şeybe, Musannef, Mektebetü'r-Rüşd, Riyad 1409, VI, 72 (29557).

45 Aliyu'I-Kârî, Mirkât, III, 1123 (1528); Aclûnî, Keşfu'l-hafâ, I, 230 (614). Burada şu bilgilere yer verilmektedir: Sehâvî el-Mekâsıd'ta Gazzalî'den rivayet eder. Aliyu'l-Kârî akabinde bu ifade bu makamda uygun düşmemiştir. Dedim ki: “و أنا مندرسة قلوبهم لاجلي" rivayetiyle birlikte bu iki hadis merfu olarak aslı yoktur.

46 Bk. Taberânî, el-Mucemu'l-kebîr, XII, 320 (807); Aliyu'I-Kârî, Mirkât, III, 1143 (1569); Mâverdî, Ebu'lHasen Ali b. Muhammed, Edebu'd-dünya ve'd-dîn, Mektebetu'I-Hayat, 1986, I, 288; Gazzalî, inyâ, Dâru'lMarife, Beyrut ty., IV, 345 (lafız farklılıklarıyla birlikte); ibn Manzûr, Muhtasar tarihi Dımeșk li ibn Asâkîr, thk. Heyet, Dâru'l-Fikr, I. bs., Dımeşk, 1984/1402, XVIII, 167; XXIII, 11; Irakî, el-Muğnî, Lübnan, Dâru İbn Hazm, 2005, I, 1712. Irakî hadisi Taberânî'nin el-Mucemu'l-kebîr'de İbn Hıbbân'nın ed-Duefâ'da zikrettiğini söyledikten sonra isnadının “zayıf” olduğunu belirtir; Münâvî, Feydu'l-kadîr, Mektebetü’tTicâriyyeti'l-Kübrâ, Mısır 1356, IV, 470 (8484); Elbanî, “zayıf” olarak hükmetmiştir; Elbanî, Silsiletu'lehâdis'd-daîfe, Daru'I-Mearif, I.bs, Riyad 1992, II, 3 (505); II, 169 (747), her iki yerde de hadisin “çok zayıf" olduğunu söyler. 
Resûlullah'ın haber verdiğine göre Allah Teâlâ “Bir kimse tek başına beni anarsa, ben de onu Zâtımda anarım. Yine bir kimse Beni bir topluluk içinde anarsa, Ben de onu o topluluktan daha hayırlı bir topluluk içinde anarım." buyurmuştur. ${ }^{47}$

Müellifin sahâbî râvîsini vermediği bu rivayeti Ebû Hüreyre bazı lafız farklıı̆̆ı ile rivayet etmektedir.

[6a] Hadis no: 22

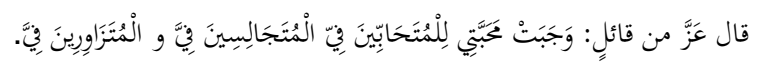

Allah Teâlâ: "Muhabbetim benim için birbirlerini sevenlere, birbirleriyle oturanlara ve birbirlerini ziyaret edenlere vacip olmuştur." buyurmuştur. ${ }^{48}$

Müellifin sahâbî râvîsini belirtmediği bu rivayet kaynaklarda bazı lafız farklılıklarıyla yer almaktadır.

[6b] Hadis no: 23

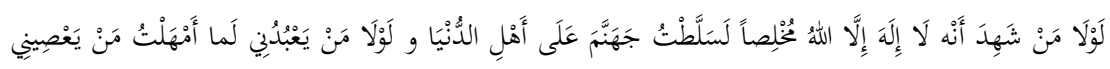<smiles>[13CH]#C[Mg]</smiles>

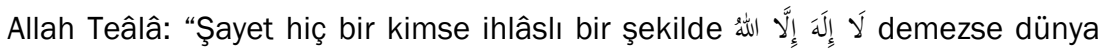
ehline cehennemi musallat ederim. Hiç kimse bana ibadet etmezse bana asi olana göz açıp kapayıncaya kadar da olsa mühlet tanırım."

Müellifin sahâbî râvîsini belirtmediği bu rivayete bu şekliyle ulaşamadık. Ancak Hilyetu'l-evliyâ'da ${ }^{49}$ yer alan rivayette, Mûsâ (a.s.) üzerinden söylenmekte ve müellifin söz konusu metnin bazı kısımlarını naklettiği görülmektedir.

[6b] Hadis no: 24

$$
\text { قال عزَّ من قائل: ما وَسَعنى أرضضي وَ لاَ سَمَائي ولكن وَسعَنى قَلْبُ عبدٍ مُؤَمنٍ. }
$$

Allah Teâlâ: “Ne yeryüzüm ne gökyüzüm beni kuşatamadı, ama mü’minin kalbi kuşattı." buyurmuştur. 50

Müellifin râvîsini zikretmeden rivayet ettiği hadisi bulamadık. Ancak kaynaklarda bu mânaya yakın farklı rivayetler bulunmaktadır. ${ }^{51}$

[6b] Hadis no: 25

\footnotetext{
47 Ahmed, Müsned, II, 354 (405).

48 Bk. Şaşî, Ebû Saîd el-Heysem b. Kuleyb b. Sureyc b. Ma'kıl, Müsned, thk. Mahfuzurrahman, Mektebetü'lUlum, Medine, 1410, I. bs., III, 278 (13829); Lafız farklılı̆̆ı ile birlikte bk. Şaşî, Müsned, III, 158 (1235); Tahâvî, Ebû Cafer Ahmed b. Muhammed b. Selame el-Ezdî el-Mısrî, Şerhu müşkili'l-âsâr, thk. Şuayb Arnavud, Müessesetü'r-Risâle, I.bs., Beyrut 1415, X, 35 (3893).

49 Bk. İsfehânî, Hilye, Daru'l-Kitabi'l-Arabi, Beyrut 1405, II, 343; VI, 32; VI, 37.

50 Böyle bir rivayete rastlamadık.

51 Bk. İbnu'I-Mübârek, Ebû Abdirrahman, ez-Zühd ve'r-rekâik, thk. Habîburrahmân el-Azamî, Dâru'I-Kütübi'lIIlmiye, Beyrut 2010, I, 540 (1543); Nisabûrî, Hilye, Saadet Matbaası, Mısır 1974, I. bs., VI, 63.
} 


$$
\text { أَتَتََْهُ هَرْوَلَّ. }
$$

Allah Teâlâ: “Kim bana bir karış yaklaşırsa ben ona bir zıra' yaklaşırım. Kimb bir zıra' yaklaşırsa ben de ona bir kulaç yaklaşırım. Kim bana yürüyerek gelirse ben de ona koşarım." ${ }^{2}$ buyurmuştur.

Müellif hadisin sahâbî râvîsini belirtmemiştir.

[6b-7a] Hadis no: 26

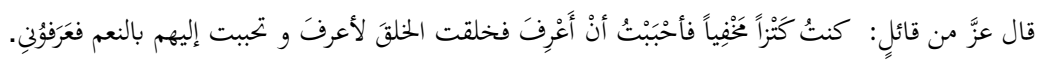

Allah Teâlâ: "Ben gizli bir hazine idim, bilinmek istemekten hoşlandım. Bilinmek için mahlûkatı yarattım. Ve nimetlerimle kendimi tanıttım beni bildiler.” 53

Müellif hadisin sahâbî râvîsini belirtmemiştir.

[7b] Hadis no: 27

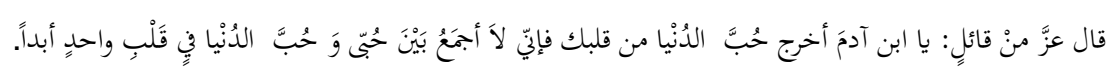

Allah Teâlâ: “Ey Âdemoğlu! Dünya sevgisini kalbinden çıkar! Muhakkak ki ben dünya sevgisiyle beraber kendi sevgimi asla bir kalpte bir araya getirmem."

Müellifin sahâbî râvîsini vermediği bu rivayete kaynaklarda rastlamadık.

[7b] Hadis no: 28

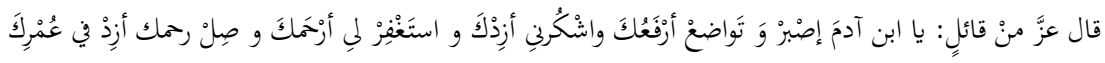

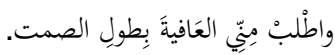

Allah Teâlâ: “Ey Âdemoğlu! Sabret ve tevazu göster ki (makamını) yücelteyim, bana şükret -(malını) artırayım, istiğfar et ki seni bağışlayım, sılayı rahim yap ki ömrünü uzatayım. Benden sessizce afiyet iste." 54

Müellifin sahâbî râvîsini vermediği bu rivayeti kaynaklarda bulamadık.

\section{[7b] Hadis no: 29}

52 Buharî, Halku Efaili'l-ibâd, thk. Abdurrahmân Umayra, thk., Dâru'l-Meârif Riyad ty., I, 94; Nisâbûrî, Hilye, VII, 268.

${ }^{53}$ Râzî, Mefâtihu'I-gaybu'l-gayb, Dâru'l-Kütübi'l-IImiyye, I.bs., Beyrut 2000, XXVIII, 194; Aclunî, Keşfu'I-hafa, I, 166 (67). Şunlara yer verir; Sûfîlerin sözlerinde sıkça yer almaktadır. Bu rivayete itimat etmişler ve bunun üzerine usul bina etmişlerdir. Aliyu'l-Kârî, manasının sahîh olduğunu söylemiştir. İttifakla aslı yoktur. Ne sahîh ne de zayıf bir senedi yoktur. İbn Teymiye, Mecmuu'l-fetevâ'da XVIII, 22'de böyle söylemiştir. el-Elbanî, bu ifadeye ondan sonra gelenler de tabi olmuşlardır dedikten sonra Zerkeşî, et-Tezkiretu fi'l-ehâdis'l-mevdûa, Beyrut, Dâru'I-Kütübi'l-IImiyye, 1986, I. bs. 136; Sehâvî, el-Mekâsıdu'l-hasene, Dâru'l-Kitâbi'l-Arabî, yy. ty., 838 zikretmişlerdir. Sehâvî şunları söylemektedir: Bu ifadeye Zerkeșî ve şeyhimiz yani İbn Hacer, Suyûtî, ed-Dürer, s. 330'da tabi olmuşlardır. Kendisi Zeylu'l-ehadisi'l-mevdûa, s. 203'de İbn Teymiye "mevzu” demiştir der. Kendisine ibn Arrâk “Tenzihu'ş-şerîa” da, Fettenî Tezkiretu'lmevdûa, s. 11'de Aliyu'l-Kârî el-Mevdûatu'l-kübrâ, (273/353) tabi olmuşlardır.

54 Reşid Efendi nüshasına göre. 


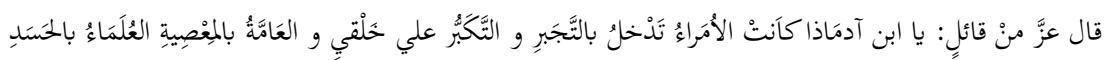

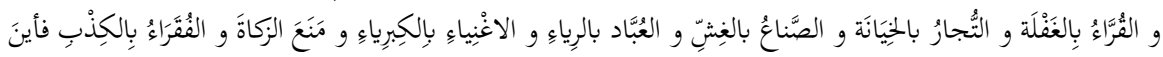

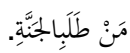

"Ey Âdemoğlu! Şayet idareciler gurur ve böbürlenerek yaratıklarım arasına giriyorlarsa; halk günah, âlimler kıskançlık, kurra/Kur'ân hafızları gaflet, tüccar hıyanet içinde ise; imalatçılar aldatıyorlar, âbidler riyakârlık gösteriyor, zenginler gururlu olup zekâtlarını vermiyorlarsa ve fakirler de yalancı ise cenneti isteyenler nerede?"55

Müellif sahâbî râvîsini zikretmediği bu rivayete kaynaklarda ulaşamadık.

[8a] Hadis no: 30

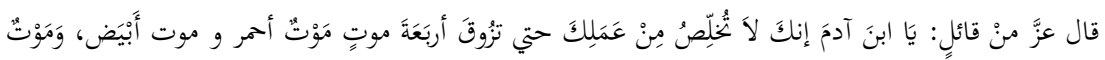

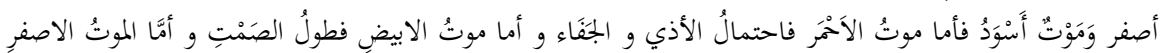

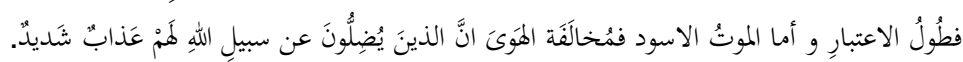

“Ey Âdemoğlu! Muhakkak ki sen şu dört ölümü tatmadıkça amellerinden -hesaba çekilmekten -kurtulamazsın: Bu ölümler: beyaz ölüm, sarı ölüm, siyah ölüm ve kırmııı ölümdür. Kırmızı ölüm, eza ve cefaya sabırdır. Beyaz ölüm ise (seni ilgilendirmeyen şeyleri terk edip) fazla konuşmamak, sarı ölüme gelince o,ömür boyunca edebliolmak. Siyah ölüm ise hevâ ve hevese muhalefet etmektir. İnsanları Allah'tan uzaklaştırıp saptıranlar için çetin bir azap vardır."

Müellifin sahâbî râvîsini kaydetmediği bu rivayete kaynaklarda ulaşamadık. Ancak bu haber, lafız farklılıklarılla birlikte Hâtim el-Asamm'ın bir sözü olarak Beyhakî̀nin Şuabü'l-îman adlı eserinde ${ }^{56}$ yer almaktadır.

[8a] Hadis no: 31

$$
\begin{aligned}
& \text { قال عزَّ من قائلٍ: يا ابن آدمَ ملائكتي يتعاقبون الليل و النهار عليك يكتبون ما تقول تفعل و الارض تشهد عليك }
\end{aligned}
$$

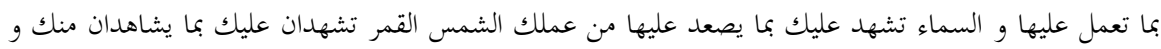

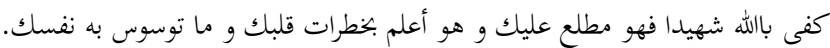

“Ey Âdemoğlu! Meleklerim (seni) gece ve gündüz takip edip. Senin yaptığın ve söylediklerini kaydederler. Yeryüzü senin yaptıklarına şahit olur, gökyüzü senden

\footnotetext{
55 Reşid Efendi nüshasinda يطلب şeklinde yer almaktadır.

${ }^{56}$ Beyhakî, Şuabu'l-imân, thk. Abdu'I-Ali Abdulhamid Hamid, Mektebetü'r-Rüşd, I. bs., Riyad 2003/1423,

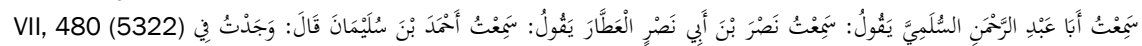

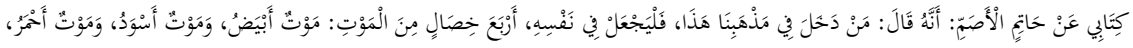

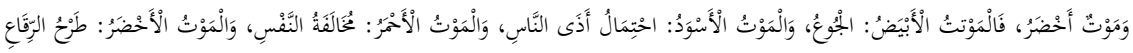

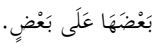


kendisine yükselen (amellerine) şahitlik eder. Güneş ve ay senden gördüklerine şahitlik ederler. Ayrıca Allah şahit olarak yeter. O sana muttalidir. 0 senin kalbinden geçenleri ve nefsinin sana verdiği vesveseleri bilir."

Müellif, hadisin sahâbî râvîsini zikretmemiştir. Kaynaklarda böyle bir rivayete ulaşamadık.

[8b] Hadis no: 32

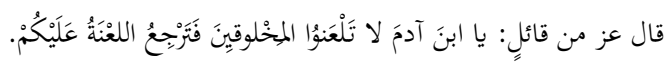

Allah Teâlâ: “Ey Âdemoğlu! Mahlûkata la'net etme, zira o lânet (daha sonra) size döner." buyurdu.

Müellifin ravisini vermediği bu rivayete kaynaklarda ulaşamadık.

[8b] Hadis no: 33

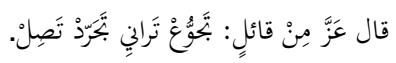

Allah Teâlâ: “Aç kal, beni gör, yalnız kal (bana) ulaş.” buyurdu.

Kaynaklarda bu mânada bir rivayet bulamadık.

[9a] Hadis no: 34

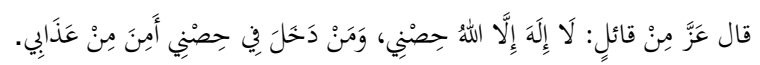

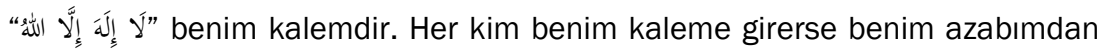
emin olur." 57

Müellifin sahâbî râvîsini vermediği bu rivayet aşağıda verilen hadisin bir kısmıdır. Bu, Ali b. Ebî Tâlib tarafından rivayet edilmektedir. 58

57 Râzî, Mefâtih, XXVI, 420; Kudâî, Müsned, II, 323 (1451); Münâvî, Feydu'l-kadîr, III, 378 (3694), Elbanî "zayıf" olarak hüküm bildirmiştir; Irakî, Ebu'l-Fadl Zeynuddin Abdurrahim b. el-Hüseyin, el-Muğni an hamli'l-esfâr fi'l-esfîr fî tahrîc mâ fí'l-ihyâ mine'l-ahbâr, Dâru ỉbn Hazm, I. bs, Lübnan 2005, I, 197., Aliyu'l-Kârî, Mirkâtu'l-mefâtîh, II, 773 (975); Suyûtî, el-Fethu'l-kebîr fì dammi'z-ziyâde ile'c-cezmi's-sağîr, thk. Yusuf en-Nebhanî, Dâru'l-Fikr, I. bs., Beyrut, 2003/1423, II, 65; Hindî, Alauddin Ali b. Hıâm, Kenzu'l-ummâl, thk. Saffet Saka-Bekri Hayatî, Müessesetü'r-Risâle, V. bs., 1981-1401, I, 52 (158); Suyûtî, Abdurrahman b. Ebî Bekr, Câmiu'l-ehadis, tahric. Hasen Abbas Zeki, Mısır t.y., b.y.y., XII, 105 (11540), XV, 65 (14988), XXIV, 206 (26985).

58 İbn Arrâk, Nureddin Ali b. Muhammed, Tenzîhu'ş-şerîati'l-merfûati ani'l-ahbari'ş-şenia el-Mevdûa, thk. Abdulvehhâb Abdullatif-Abdullah Muhammed es-Sıddık el-Gumarî, thk. Abdulvehhâb Abdullatif-Abdullah Muhammed Sıddık Gumarî, Dâru'I-Kütübi'I-IImiye, I. bs., Beyrut 1399, I, 147 (39); Suyûtî, el-Leâli'lmasnûa fi'l-ehâdis'l-mevdûa, thk. Ebû Abdirrahman, Salâh b. Muhammed b. Uveyda, Beyrut, Daru'I-Kütübi'I-ilmiyye, 1996/1417, I. bs., I, 178; Deylemî, Şiruveyh b. Şehredar b. Şiruveyh b. Fenahüsrev, elFirdevs bi mesuri'I-hitâb, Dâru'I-Kütübi'l-IImiyye, Beyrut 1986/1406, I. bs., V, 251 (8101); Elbanî, Daifu el-Camii's-sağîr ve ziyadetihi, kontrol. Zuheyr eş-Şaviş, Mektebetü'l-ìslamî, Beyrut 1988, I, 399 (2700), "zayıf" olarak hükmetmiştir. İsfehânî, Hilye, III, 192. Hadis bu isnad ile meşhurdur. Bu isnad tahir kimselerin babaları temiz olan kimselerden yaptıkları bir isnattır (ehl-i beyt tariki). Selefimiz bazı muhaddis-

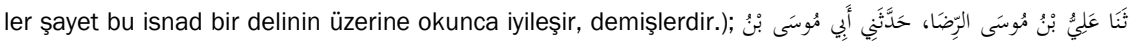

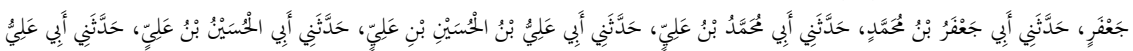

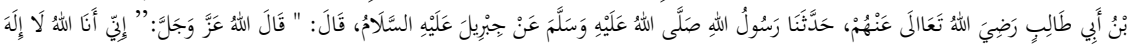


[9a] Hadis no: 35

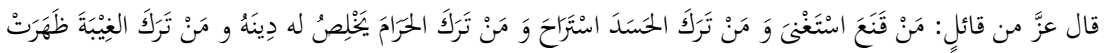

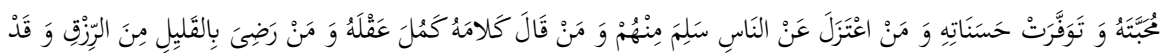

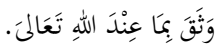

“Kim kanaat ederse zengin olur, kim kıskançlığı terk ederse rahat eder, kim haramı terk ederse dinini korur, kim gıbeti terk ederse ona olan muhabbetim zâhir olur ve güzel işleri çoğalır, kim halktan uzaklaşırsa onlardan güvende olur. Kim az konuşursa aklı kemale ermiştir, kim rızık konusunda aza razı olursa Allah Teâlâ'nın (azabından) güvende olur."

Müellifin sahâbî râvîsini belirtmediği bu rivayeti kaynaklarda bulamadık.

\section{[10b] Hadis no: 36}

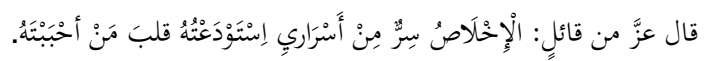

“inlas, benim sırlarımdan bir sırdır. Bu sırrı ben sevdiğim (kulumun) kalbine koydum." 59

Sahâbî râvî zikredilmeyen bu rivayet, ilgili dipnotta yer verdiğimiz üzere, uzun bir rivayetin parçasıdır.

[10b] Hadis no: $\mathbf{3 7}$

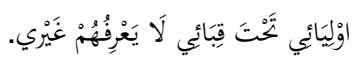

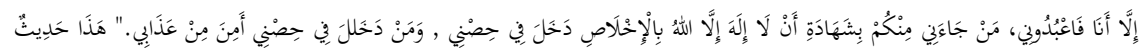

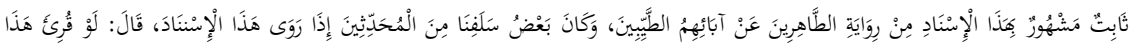

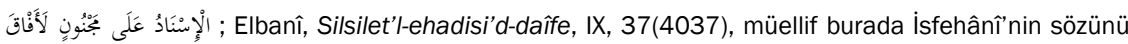
naklettikten sonra Irakî’nin İsfehânî rivayet ettiği hadis hakkında "merdud" ifadesini nakleder.

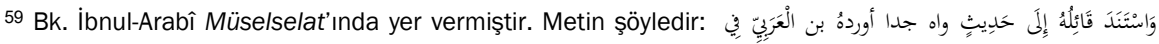

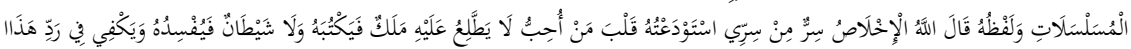

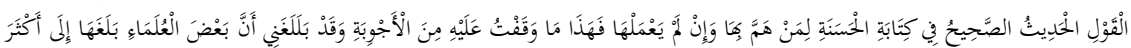

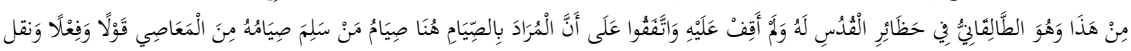

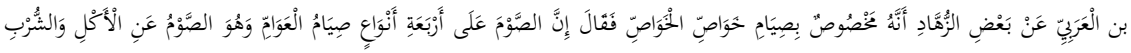

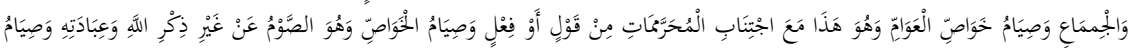

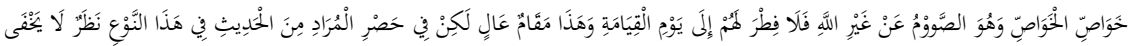
Ibn Hacer hadisin çok zayıf olduğuna işaret etmektedir. Bk. İbn Hacer, Fethu'I-bârî șerhu sahîhi'l-Buharî, tashih. Muhubiddin el-Hatib, numaralama: Fuad Abdulbaki; talik. Abdulaziz b. Abdillah b. Bâz, Dâru'l-Fikr, Beyrut 1379, IV, 108. Ayrıca bk. Aynî, Ebû Muhammed Mahmud b. Ahmed, Umdetu'l-kârî şerhu sahîhi'l-buharî,, Beyrut, Daru inyai't-Turasi'I-Arabi, yy. ty., X, 261; Aliyı'I-Kârî, Mirkât, I, 62; Zurkânî, Muhammed b. Abdilbakî, Şerhu'zzurkânî alel-Muvatta, Daru'I-Kütübi'I-IImiye, I. bs., Kahire 2003/1424, II, 297; Elbânî, Ebû Abdirrahman Muhammed Nasıruddin, es-Silsiletu'd-daiffe ve mevdûa ve eseruha es-seyyie fi'l-ümme, II, 92 (603). 
"Velî kullarım benim korumam (elbisemin) altındadır, benden başkası onları bilemez."60

Müellif, bu hadisin sahâbî râvîsini kaydetmemiştir.

[10b] Hadis no: 38

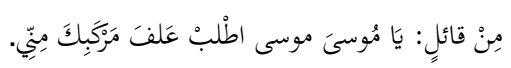

“Ey Mûsâ! Merkebinin otunu bile benden iste!”

Râvisi zikredilmeyen bu rivayete ulaşamadık.

[10 b] Hadis no: 39

$$
\text { قَالَ عَزَّ مِنْ قائلٍ: يَا مؤسيَ دَعْ نَفْسَكَكَ تَعَالْ. }
$$

“Ey Mûsâ! Nefsini bırak ve gel!”

Râvisi zikredilmeyen bu rivayete ulaşamadık.

[10b] Hadis no: 40

$$
\text { قال عزَّ مِنْ قَائلٍ: يَا مُوسيَ اجْعَلْ في طَعَامكَ. }
$$

“Ey Mûsâ! Yemeğini/aşını yap!”

Râvisi zikredilmeyen bu rivayete ulaşamadık.

Şimdi eserde yer alan hadislerin dağılımına geçebiliriz.

60 Aliyu'l-Kârî, Mişkâtu'l-Mesâbih, VIII, 3339 (5328); Rivayet ayrıca Münâvî, Abdurraûf, et-Tevkıf ala muhimmati't-teârif, Dâru'I-Fikr, I. bs., Kahire 1990/1410, I, 315'de yer almaktadır. Burada yer alan dipnotta Aliyyu'I-Kârî'nin Şerhu'ş-Şemâil'de zikrettiğini fakat hadisi Peygamber(s.a)'e ref etmediği şeklinde bir bilgi yer almaktadır. 


\begin{tabular}{|c|c|c|c|c|c|}
\hline Hadis No & Âyet & Kudsî Hadis & Nebevî Hadis & Beyt & Selef Sözü \\
\hline 1 & -- & -- & 2 & -- & -- \\
\hline 2 & -- & -- & -- & 1 & -- \\
\hline 3 & --- & 1 & --- & -- & -- \\
\hline 4 & -- & 1 & --- & -- & --- \\
\hline 5 & -- & --- & --- & -- & -- \\
\hline 6 & --- & 1 & --- & --- & --- \\
\hline 7 & --- & 1 & --- & -- & 1 \\
\hline 8 & -- & --- & -- & -- & 1 \\
\hline 9 & 2 & 2 & --- & 1 & --- \\
\hline 10 & --- & -- & --- & -- & -- \\
\hline 11 & --- & --- & --- & -- & --- \\
\hline 12 & -- & -- & -- & --- & -- \\
\hline 13 & --- & --- & --- & -- & -- \\
\hline 14 & --- & --- & -- & -- & -- \\
\hline 15 & 3 & 3 & 2 & 1 & --- \\
\hline 16 & 1 & 2 & 1 & 1 & --- \\
\hline 17 & --- & --- & --- & -- & -- \\
\hline 18 & --- & --- & --- & -- & --- \\
\hline 19 & -- & --- & -- & -- & -- \\
\hline 20 & --- & --- & --- & -- & -- \\
\hline 21 & --- & --- & --- & -- & -- \\
\hline 22 & -- & --- & --- & -- & -- \\
\hline 23 & --- & --- & 3 & -- & -- \\
\hline 24 & --- & --- & --- & -- & -- \\
\hline 25 & --- & --- & -- & -- & -- \\
\hline 26 & 1 & --- & 3 & 1 & --- \\
\hline 27 & 1 & --- & 2 & 1 & --- \\
\hline 28 & --- & --- & -- & --- & --- \\
\hline 29 & --- & --- & 1 & --- & --- \\
\hline 30 & 1 & --- & -- & --- & --- \\
\hline 31 & --- & -- & --- & --- & --- \\
\hline 32 & 1 & --- & --- & --- & 1 \\
\hline 33 & --- & --- & --- & -- & --- \\
\hline 34 & 1 & --- & 1 & -- & --- \\
\hline 35 & 2 & 2 & 5 & 1 & --- \\
\hline 36 & --- & --- & --- & -- & --- \\
\hline 37 & --- & --- & --- & --- & --- \\
\hline 38 & - & --- & --- & -- & -- \\
\hline 39 & - & --- & -- & -- & -- \\
\hline 40 & --- & 2 & 1 & --- & --- \\
\hline Toplam & 13 & 15 & 21 & 7 & 3 \\
\hline
\end{tabular}

Yukarıda verdiğimiz tablonun değerlendirmesini yapacak olursak, görüldüğü gibi, müellif hadislerin şerhi esnasında gerek âyet gerekse hadis-i kudsî ve hadis-i şeriflerden faydalanmıştır. Ancak burada dikkat çeken bir husus, kırk hadislerde olduğu gibi burada da zayıf hatta uydurma rivayetlere yer verdiğidir. 
Sıhhati itibariyle Aksarayî'nin eserinde yer verdiği 40 hadisten 17 adedi sahih, 3 adedi mevzu/uydurma, 5 adedi zayıftır. Şerh esnasında istişhad olarak 8'i kudsî hadis olmak üzere 28 hadis kullanmıştır. Bu kudsî hadislerden 4 tanesinin kaynağını tespit edemedik. Diğer 4 rivayet ise mevzudur. 16 rivayeti kaynaklarda bulamadık. İstişhad için kullanılan rivayetlerden 1 tanesi sahih, 4 tanesi zayıf, 6 tanesi mevzu, 1 tanesi de selef sözü olup hadis değildir.

\section{5. ŞERHU ERBAÎNE HADISEN KUTSIYYEN ADLI ESERIN USLÛB VE METOT BAKIMINDAN DEĞERLENDIRILMESI}

Müellifimiz hadisleri şerh ederken "işârî metodu" esas almış ve buna göre hadisleri yorumlamıştır. Bu metodun adını aldığı işaret kelimesi, sözlükte bir şeye kafa, kaş, göz ile özellikle de parmak veya elle işarette bulunmak, göstermek demektir. ${ }^{61}$ Bu tanımdan anlaşılan söz olmaksızın yapılan hareket îmada ya da telmihte bulunmak demektir. "işarî yorum” ise hadisleri işaret ve ima/üstü kapalı62 yoluyla şerh etmektir. Bu yorumda genellikle nas daha çok sözlük anlamının dışında yorumlanır.

Sûfîler de diğer âlimler gibi hadisleri, Kur'ân-ı Kerîm'den sonra ikinci kaynak olarak ele almışlardır. Onlar her ne kadar daha çok ahlak, zühd ve irfan ile alâkalı hadislere ağırlık vermiş olsalar da yaptığımız bu çalışmada görüleceği gibi İslam'ın temel esaslarına yer veren hadislerle birlikte adâb ve diğer konulara da yer vermişlerdir.

Kur'ân-ı Kerîm sembolik yollarla tefsir edildiği gibi, hadislerin de işârî şerhleri yapılmıştır. Daha çok “nefsin terbiye edilmesi”ne ağırlık veren bu tefsirler, zühd hareketi dediğimiz ilk asırlardan itibaren İslâm dünyasında revaç bulmuştur. Müellifimizin de hadisteki şerh metodu bu şekildedir. Örneklemelerinde de görüleceği üzere tamamen insanı terbiye etme üzerinedir. Genel olarak sûfîlerin kırk hadis türü çalışmalarda hadisleri seçerken, daha çok fıkhî intilaftan uzak olanları tercih ettikleri görülmektedir.

İşârî yorumların özelliklerini birkaç başlık altında toplayabiliriz. Bunlar:

1- Kelimenin sözlük anlamından uzaklaşmak ve kavram farklılıkları,

2- Mevzu ve zayıf rivayetleri kullanmaları,

3- Şerh esnasında farklı konulara meyletmedir.

Şimdi bunlara dair örnekleri zikredebiliriz.

\subsection{Kelimenin Sözlük Anlamından Uzaklaşması ve Kavram Farklılıkları}

Tasavvuf ehlinin kavramları kendi aralarında farklılık arz edebilmektedir. Müteşâbih kelimelerin kullanımasının yanı sıra sembolik dilin kullanılması, onların yorumlamalarını zorlaştıran unsurlardır. Nitekim İbn Kayyim el-Cevziyye (ö. 751/1351)

61 ibn Manzûr, Lisânu'l-arab, Daru Sadır, I. bs., Beyrut ty., IV, 434.

62 ibn Manzûr, Lisânu'l-arab, V, 536. 
bu duruma şöyle dikkat çekmiştir: "Sûfîlerin sözlerinde istiareler vardır. Onlar bazen hassı/özel kastederler, ancak âmm/genel ifade kullanıverirler. Söyledikleri sözün işareti ile hakikî/gerçek mânasının haricinde kendilerinden başka hiçbir cemaatin lisanında olmayan bir anlam kastedebilirler. Bundan dolayıdır ki "Bizler işaret ashabıyız, ifade ashabı değil. İşaret bizim, ifade bizim dışımızdakilerindir" derler. Onlar, bazen mülhitlerin kullandıkları ifadeleri kullanırlar ve bununla da dar mânayı kastetmezler. Bu da iki kısım için çatışma unsuru olmuştur. Bir kısım tasavvuf ehli hakkında onların ifadelerinin zâhirine hamlederek bid'atçi ve sapık olduklarını ileri sürerken diğer grup da tasavvuf ehlinin maksatlarına bakar ve kullandıkları bu ifadeleri ve işaretleri sahih kabul ederler. Hakka aykırı olanları da kim olursa olsun reddeder."63

Buna dair bazı misâller şunlardır:

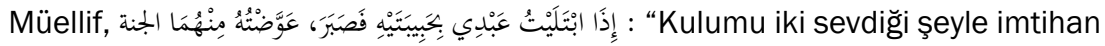
ettiğimde sabrederse o ikisi karşılığında cenneti veririm."64 rivayetinde yer alan

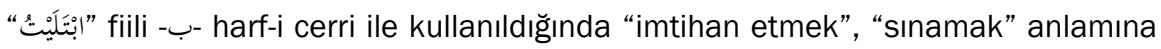
gelmektedir. Bu fiilden türemiş olan البَلاءُ kelimesi ise sözlükte imtihan, müsibet, hüzün ve keder gibi anlamlara gelirken müellif onu “hicap” anlamında yorumlamakta ve "sanki Allah Teâlâ şöyle demek istemiştir: "Şayet ben isimlerimin nurlarıly ve kulum arasına bir hicap koyarsam Sabûr ismi mazhar olur..." diyerek, kelimenin aslî manasından uzaklaştırmaktadır.

$$
\text { Allah }
$$
şöyle buyurdu; "Bir kimse Bana bir karış yaklaşırsa Ben ona bir arşın yaklaşırım. Bir kimse Bana bir arşın yaklaşırsa Ben ona bir kulaç yaklaşırım. Bir kimse Bana yürüyerek gelirse Ben ona koşarak giderim." hadisinde yer alan “تلقى" kelimesinden maksat Allah'a yakın olmak için kulun ârif bir kimseye hizmet etmeyi seçerek dünyayı terk etmesidir diyerek kelimenin sözlük anlamından uzaklaşmaktadır. Halbuki “"قلى" fiilinden türeyen “تلقى” fiili “karşılamak, kabul etmek, ders almak” gibi mânalara gelmektedir.

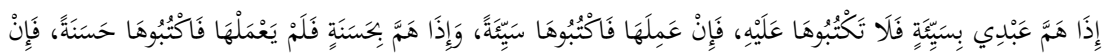

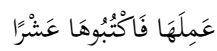

Allah Azze ve Celle şöyle buyurdu: “Şayet kulum bir günah işlemeye niyet etse ama yapmasa ona günah yazmam, şayet o günahı işlerse o günahın karşıı̆ını yazarım. Güzel bir iş yapmaya niyetlense ve onu yapmasa da ona sevap yazarım. Şayet

63 İbn Kayyim, Medâricü's-sâlikîn, Dâru'l-Kitabi'l-Arabî, II.bs., Beyrut 1973, III, 330,331.

64 el-Aksarayî, Şerhu erbaîn, Esat Efendi Bölümü nu: 314, 2/a. 
o güzel işi yaparsa ona on misli sevap yazarım”. Bu hadiste yer alan بِ بِيَّة /es-Seyyie'den maksadı ise el-Aksarayî: "Evliyânın ve avamının ibadet ve tâatların nurlarına bakılması veya evliyânın havâssına bakılarak Allah'ın isimlerinin ve fillerinin veya çok özel kullarına bakılarak sıfatlarının nurlarının fark edilmesidir" diyerek, kelimenin sözlük anlamından uzaklaşmış görünmektedir. Başka bir örnek ise:

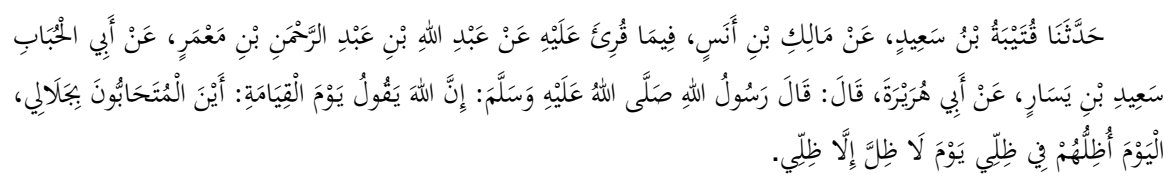

Allah (c.c.) kıyamet gününde “Celâlim için birbirlerini sevenler nerede?”65 diye soracak ve onları hiç bir gölgenin olmadığı bu günde kendi gölgemle gölgelendireceğim" buyuracağına dair hadistir.

el-Aksarayî, hadiste yer alan sevmek manasına gelen الخبة/muhabbet'ten kasıt “Başkasına muhabbeti nefyeden Allah'ın zatına olan muhabbettir” der. Sanki Allah Teâlâ şöyle demektedir: "Celâlim ve azametim vasıtasıyla benim için zatımın sevgisinin denizinde derinleşenler nerede?" diyerek mahlûkatın birbirine olan sevgisini red etmiş olmaktadır.

el-Aksarayî, “ للا موجود الا هو denildiği gibi bugün onlara ben benim varlığımdan başka varlık olmayan varlığımın/vücûd nuruyla tecelli ettim. Vücûd-i hakikî zâhir olmadıkça kemâl-i istirahat olmaz bilesin" şeklinde yorumlayarak aşkın bir anlam katmıştır.

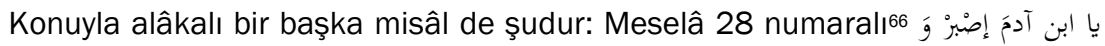

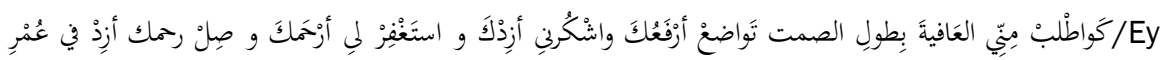
Âdemoğlu! Sabret ve tevazu göster (makamını) yücelteyim, bana şükret (malını) artırayım, istiğfar et ki seni bağışlayım, sıla-ı rahim yap ki ömrünü uzatayım. Benden sessizce afiyet iste" mealindeki hadistir. Hadisin yorumunda şu bilgilere yer vermiştir:

el-Aksarayî, “Bilesin ki Hakk Sübhânehû Teâlâ şöyle buyurur: "Kulum şayet bu dünyada benim ahlâkımla ahlâklanırsa, miskinlik ve fakirliği seçerse varlığımın nuruyla ona في العقبى/ukbâda tecellî ederim...." rivayetini; sabır ve tevâzuyu miskinlik ve fakirlik şeklinde yorumlayarak kelimenin aslî mânasından uzaklaşmasının yanı sıra fakirliği ve miskinliği övmesi ve onun sûfiliğin aslı olduğu intibaını vermesi ayrıca sılai rahim konusuna temas etmemesi de oldukça dikkat çekicidir. ${ }^{67}$

\footnotetext{
65 el-Aksarayî, Şerhu erbaîn, Esat Efendi Bölümü nu: 314, 4/a.

66 el-Aksarayî, Şerhu erbaîn, Esat Efendi Bölümü nu: 314,7/b.

67 el-Aksarayî, Şerhu erbaîn, Esat Efendi Bölümü nu: 314, Hadis nu. 3.
} 


\subsection{Mevzu ve Zayıf Rivayetleri Kullanması}

Muhaddislerin'88 fedâil-i a'mâl, zühd, âdâb ve ahlâk konularında zayıf hadislerle amel edilebileceği hususunda mütesâhil davranmaları, tasavvuf çevrelerinin zayıf hadislerle amel etme ve o tür rivayetleri şerh etme konusunda gevşek davranmalarına sebebiyet vermiştir. Zayıf hadislerle amel konusu intilaflı bir konu olmakla beraber bazı tasavvuf ehli sadece zayıf hadisleri değil, uydurma rivayetleri bile eserlerinde rahatlıkla kullanmışlar ve yorumlamışlardır. Müellifimiz el-Aksarayî de sûfî meşrep olmasından selefinin yolundan giderek zayıf ve uydurma haberlere eserinde yer vermekle kalmamış, ayrıca bunları yorumlamıştır. Eserdeki buna dair bazı rivayetler şunlardır:

Tasavvuf muhitinde sıkça kullanılan rivayetlerden biri olan “Nefsini (kendini) biIen Rabbini bilir"69 hadisidir. Müellifin bu rivayeti Ebû Tâlib el-Mekkî'den(386/996) aldığı anlaşılmaktadır; zira Mekkî bu rivayeti kudsî hadis olarak rivayet etmekte ve insanların da Allah (c.c.) gibi, kişinin kusurlarını itiraf etmesini ve tevazu göstermesini beklediğini söylemektedir.70

Yine müellifimizin bir yerde ismini zikrederek ${ }^{71}$ atıfta bulunduğu Ebû Tâlib elMekkî de bu rivayeti eserinde kullanarak "Insan, mahlûkata karşı muamelesinde nefsinin sıfatlarını bilirse yaratıcısının sıfatlarını da öylece bilir" şeklinde yorumlamıştır. ${ }^{72}$ el-Aksarayî başka bir hadiste nefsin mertebelerini anlatırken ${ }^{73}$ buna temas etmektedir.

Mutasavvıflardan es-Sülemî (ö. 412/1021) bu rivayeti “Yani kul kendini bilirken Rabbini bilemez. Ne vakit kendini unutursa/fenâ bulursa o zaman Rabbini bilir" şeklinde yorumlar. Ayrıca o, önemli bir noktaya temas ederek bu sözün hadis değil seleften bazılarının sözü olduğunun altını çizer. ${ }^{74}$

$\mathrm{Bu}$ ve benzeri rivayetlerin tasavvuf muhitlerinde özellikle de vahdet-i vücûd75 düşüncesinde olanlarca kullanılması, onların Muhyiddin İbnü'l-Arabî'den (ö. 638/1240) etkilenmelerinden dolayıdır. Özellikle onun Fütuhâtu'l-Mekkiye ve Fusûsu'l-hikem isimli eserleri bu hususta önemli olup kendisinden sonra gelenleri

68 Zayıf hadisle amel edilip edilmemesi konusundaki görüşler için bk: Leknevi, el-Ecvibetu'l-fadıla li'l-esileti'l-aşrati'l-kâmile, s. 228-238.

69 Ebû Nuaym, Hilye, VIII, 15; X, 205, 208; Gazzâlî, İhyâ, IV, 26, 301; Münâvî, Feyzu'l-kadîr, I, 224; IV, 399; V, 49; Aclûnî, Keşfu'I-hafâ, thk. Ahmed el-Kallâş, Müessesetü'r-Risâle, Beyrut 1996, VI. bs., II, 1529; Elbânî, Silsilet'l-ehadisi'd-daîfe, I, 165,166.

70 Bk. Ebû Tâlib el-Mekkî, Kûtu'l-kulûb fî muâmeleti'l-mahbûb ve vasfi tarîkı'l-mürî̀ ilâ makâmi't-tevhîd, thk. Asım İbrahim, Dâru'l-Kütübi'I-ilmiyye, II. bs., Beyrut 2005, II, 96.

71 Bk. el-Aksarayî, Şerhu erbaîn, Esat Efendi Bölümü nu: 314, 3/b, (8).

72 Bk. Ebû Tâlib el-Mekkî, Kûtu'l-kulûb, II, 83.

73 Bk. el-Aksarayî, Şerhu erbaîn, Esat Efendi Bölümü nu: 314, 9/a-10/a, (35).

74 Sülemî, Mes'eletü Derecâti's-sâdikîn, thk. Süleyman Ateş, (Tis'atu Kutub Li Ebî Abdirrahman es-Sülemî içinde), Ankara 1981, s. 147.

75 ỉbn Arabî, el-Fütuhâtü'l-mekkiyye, Dâru'l-Fikr, Beyrut 1994, I, 733; II, 41, 154 vd. 
oldukça etkilemiştir. Bu hususa muhaddis Nevevî de (ö. 676/1277) dikkat çekmektedir. ${ }^{76}$

Sadedinde olduğumuz rivayet hakkında ilk defa derli toplu bilgi veren âlim İbn Teymiyye'dir (ö. 728/1328). O konuyla alâkalı olarak şunları söyler: “Bazı kimseler bu rivayeti Resûl-i Ekrem'den rivayet etmekte iseler de onun sözü değildir. Zira bu rivayet, hadis kaynaklarında yer almadığı gibi hadisin isnadı da bilinmemektedir. Sözün mânası ister sahih olsun isterse fâsid olsun kendisiyle inticac edilemez. ${ }^{77}$ ibn Teymiyye'nin talebesi olan İbn Kayyim (ö. 751/1351) de rivayetin Hz. Peygamber'e ait olmadığını ve farklı lafızlarla isrâiliyattan geçtiğini belirtir.78 Aclûnî (ö. 1162/1749), Nevevî'nin hadis hakkında “Allah Resûlü'nin sözü olmadığı” değerlendirmesinde bulunduğunu; İbn Teymiyye'nin bu rivayete “mevzu” dediğini, İbnu'sSem'anî'nin (ö. 489/1014) “bu rivayetin merfu olarak bilinmediği”, Yahya b. Muâz er-Râzî'nin (ö. 258/871) sözü olduğu" şeklindeki ifadeleri nakleder.79 Elbânî de (ö. 1999) "bu haberin aslı yoktur" 80 değerlendirmesinde bulunmuştur.

Görüldüğü üzere hakkında; “mevzû”, “aslı yoktur” veya "isrâiliyattandır” gibi değerlendirmeler yapılan bu haberin tasavvuf muhitinde yer bulması, Rabbin kul tarafından bilinmesine işaret etmesinden kaynaklanmaktadır. Ebû Tâlib el-Mekkî̀nin kudsî hadis olarak naklettiği bu rivayeti el-Aksarayî de kudsî hadisler arasında zikretmiştir. Sülemî'nin "Bu, seleften bazı kimselerin sözüdür" şeklindeki ifade kendisinden sonra gelen haleflerince de pek revaç bulmamış olmalı ki onu kudsî hadis olarak değerlendirmişlerdir.

Tasavvuf muhitlerinde kullanılan ve üzerine usûl bina edilen diğer bir rivayette "Ben gizli bir hazine idim; bilinmek istedim. Bu sebeple insanı yarattım ve onunla tanındım" hadisidir. Müellifimiz de selefi gibi bu rivayeti kudsî hadis olarak eserine derc etmiş bulunmaktadır. İlk dönem tasavvuf eserlerinde yer almayan bu rivayetin İbnü'l- Arabî ve halefleri tarafından sıkça kullanıldığı görülmektedir. ${ }^{81}$ İbnü'l-Arabî'nin bu rivayete eserinde yer vererek onu meşhur hâle getirdiği söylenebilir. Bu rivayet halk arasında hadis olarak meşhur olan rivayetleri eserlerinde toplayan geç dönem eserlerde ve tasavvuf kaynaklarında görülmektedir. Bu rivayet hakkında en kapsamlı açıklamayı İbn Teymiyye yaparak “Bu, Hz. Peygamber'in (s.a.v.) sözü değildir; ayrıca onun sahih ya da zayıf bir senedi bilinmez)" 82 de-

\footnotetext{
76 Aclûnî, Keşfu'l-hafâ, II, 1529.

77 ibn Teymiyye, Mecmûu'l-fetâvâ, der. Abdurrahman b. Muhammed b. Kâsım el-Asımî ve oğlu, Mecmau'lMelik Fehd litıbati'l-Mushaf eş-Şerîf, Medine-i Münevvere 1995, IX, 295-297; XVI, 349.

78 İbn Kayyim, Medâricü's-sâlikîn, Daru'I-Kitabi'I-Arabi, II.bs., Beyrut 1973, I, 427.

79 Aclûnî, Keşfu'l-hafâ, II, 1529.

80 Aclûnî, Keşfu'l-hafâ, II, 1529; Ayrıca bk. Uysal, Muhittin, Tasavvuf Kültüründe Hadis-Tasavvuf Kaynaklarındaki Tartışmalı Haberler, Konya 2002, 326-332.

81 Bk. İbn Arabî, Fütuhât, III, 198; IV, 419 vd.

82 Bk. İbn Teymiyye, Mecmûu'l-fetâvâ, XVIII, 122, 376.
} 
miştir. Aclûnî, Zerkeşî (ö. 794/1392) ve İbn Hacer (ö. 852/1448) de bu görüşe katılmışlardı. ${ }^{83}$ Keşifle hadisin sahih olduğunu ifade eden Osmanlı ulemasından İsmail Hakkı Bursevî de (ö. 1137/1724) selefi İbnü'l-Arabî gibi bu rivayetin ilhamla sıhhatine hükmetmiştir. ${ }^{84}$

Muasır hadis âlimlerinden Elbânî, ittifakla hadisin “aslının olmadığını” 85 söyler. Hadislerin ilham yoluyla tashih etme konusu ise, ilmî kriterlere dayanmadığı, sübjektif olduğu ve istismarlara yol açabileceği gibi sebeplerle muhaddisler tarafından tenkit edilerek reddedilmiştir. ${ }^{86}$

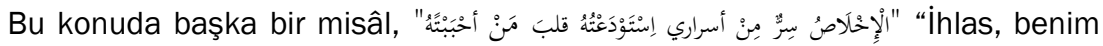
sırlarımdan bir sırdır. Bu sırrı ben sevdiğim (kulumun) kalbine koydum" 87 isimli rivayettir. İbn Hacer'in "çok zayıf" 88 olarak hükmettiği bu hadis hakkında muasır âlimlerden Elbânî de "zayıf" hükmünü verir. ${ }^{89}$

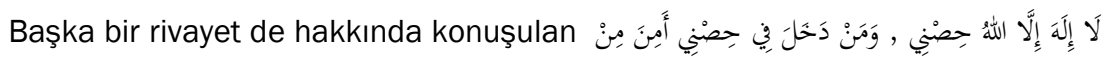
kelimesi benim kalemdir. Her kim benim kaleme girerse benim azabımdan emin olur" hadisidir.

Müellifimizin büyük dedelerinde olan er-Razi'nin tefsiri olan Mefâtîhu'l-gayb'ten aldığını düşündüğümüz bu haber hakkındaki müşterek kanaat, rivayetin sahih olmadığıdır. Âlimler rivayetin zâfiyeti hakkında farklı görüşler beyan etmişlerdir. İsfehânî, eserinde yer verdiği hadis hakkında her ne kadar "Hadis bu isnad ile meşhurdur. Bu isnad, temiz kimselerin babaları temiz olan kimselerden (Ehl-i beyt tariki) nakletmeleri suretiyle oluşmuştur. Selefimiz bazı muhaddisler "Bu isnad bir delinin üzerine okunca iyileşir" değerlendirmesinde bulunmuş olsa da Elbânî, İsfehânî’nin sözünü naklettikten sonra Irâkî'nin hadis hakkında "merdud" ifadesini nakletmiştir. ${ }^{90}$ Ancak hem Süyût $\hat{9}^{1}$ hem de ibn Arrâk ${ }^{92}$ bu hadisi "mevzu” olarak gördükleri için onu mevzu hadise hasr ettikleri eserlerinde zikretmişlerdir. İbn Arrâk hadis hakkında: “Irâkî(806/1404) Tahricü'l-ihyâ isimli eserinde bu hadisi Hâkim (405/1014), Târihu Nisâbûr, Ebû Nuaym el-İsbehânî(430/1038), el-Hilye'de Kudâî (454/1062), Müsnedu'ş-şihâb'da Ali b. Mûsâ er-Rızâ baba ve dedelerinden rivayet etmiştir. Bu kişi

\footnotetext{
83 Bk. Aclûnî, Keşfu'l-hafâ, II, 132.

84 İsmail Hakkı Bursevî, Kenz-i mahfî, Misvak Neşriyat, İstanbul 1980, 10, 11. Ayrıca bk. Rûhu'l-maânî fî tefsîri'l-Kur'ani'l-azîm, Dâru inyâi't-Türas el-Arabî, Beyrut ty., XVII, 121; XXVII, 21, 25.

85 Elbânî, es-Silsiletu'd-daife, XIII, 50, 51.

86 Bk. Leknevî, el-Ecvibetu'l-fâzıle li'l-es'ileti'l-aşrati'l-kâmile, thk. Abdulfettâh Ebû Ğudde, Mektebetu Matbuati'l-isslamiye, Beyrut 1994, s. 132-135'deki dipnotlarda verilen bilgiler.

87 el-Aksarayî, Şerhu erbaîn, Esat Efendi Bölümü nu:314, hadis nu: 36.

88 Bk. İbn Hacer, Fethu'l-bârî şerhu Sahîhi'l-Buharî, IV, 108. Ayrıca bk. Aynî, Umdetu'l-kârî, X, 261.

89 Ebû Abdirrahman Muhammed Nasıruddin, es-Silsiletu'd-daîfe, II, 92 (603).

90 Bk. el-Elbanî, Silsilet'l-ehadisi'd-daîfe, IX, 37 (4037).

91 Bk. Suyûtî, el-Leâli'l-masnûa, I, 178.

92 Bk. İbn Arrâk, Nureddin Ali b. Muhammed, Tenzîhu'ş-şeria, I, 147 (39).
} 
çok zayıf birisidir. İbn Tahir el-Keşf an ahbâri'ş-şihâb'ta, Hilye'de Ali er-Rızâ'dan yapılan rivayette Ebu's-Salt el-Herevî vardır ve ittifakla kendisi "zayıf" birisidir. Kudâî'nin eserinde yer alan rivayette ise Ahmed b. Ali b. Sadaka "müttehem bi'lkizb/hadis uydurmakla itham edilmiştir.” Deylemî'nin (ö. 509/1115) “Bu hadis sabittir ve meşhurdur" sözüne gelince, o merdûd bir ifadedir" şeklinde değerlendirmede bulunur.

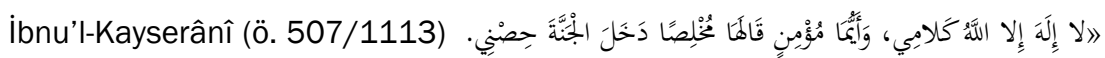
hadisi hakkında şu bilgilere yer verir: “Bunu Ebû Eşras el-Kufî, Şureyk’ten; o da Ca'fer b. Muhammed'den, o da babalarından rivayet etmiştir. Ebu'l-Eşras, Şureyk'e isand ederek hadis uydururdu. Bu rivayet el-Hâris b. Umeyr > Eyyub > Ikrime $>$ İbn Abbas tarikiyle de rivayet edilmektedir. Bu isandda yer alan el-Haris b. Umeyr yalancı birisidir. İbn Hıbbân ise "Ben bu rivayeti araştırdım ve aslını Hammad b. Zeyd > Eyyüb > İkrime > el-Abbas veya İbn Abbas tarikiyle aslının olduğunu buldum" demektedir. 93

حسنات الابرار سيئات “ Bu konuda bir başka örnek de şevahit olarak kullandığ المقربين/Ebrârın hasenatı mukarrabînin günahıdır" hadisidir. Müellifin büyük dedesi Râzî'den naklettiğini düşündüğümüz bu rivayet hakkında âlimler şu değerlendirmede bulunmaktadırlar:

“el-Fettenî (986/1578)94 ve Aliyu'I-Kârî (1014/1605)95 hadisin mevzu olduğunu söylerler ve rivayetin hadis değil el-Harrâz'ın sözü olduğuna dikkat çekerler. Aclûnî, hadisin değeri hakkında “ibn Asâkir'in biyografisinde verildiği gibi bu söz Ebî Saîd elHarrâz'ın sözüdür. Kendisi önde gelen sûfîlerdendir. 280/893 de vefat etmiştir. Bazıları bu sözü hadis saymışlardır. Halbuki böyle değildir. İbn Asâkîr bunu yine elHarrâz'ın sözü olarak da nakletmiştir. Zunnûn-i Mısrî'den (ö. 859/1455) de bu söz rivayet edilmiştir. ez-Zerkeşî (ö. 794/1392) el-Lukta isimli eserinde Cüneyd'de ait olduğunu rivayet eder"96 değerlendirmesinde bulunmuştur.

لولاك لما خلقت “ Bu kısımda son olarak el-Aksarayî’nin şevâhid olarak kullandığı الافلاك الكالك olmasaydın ben âlemleri yaratmazdım"97 hadisini örnek olarak verebiliriz. Tasavvuf muhitlerinde sıkça kullanılan bu rivayet, hadis olarak revaç bulmuş olsa da sahih kaynaklar bir yana mevzu hadis külliyatında da yer almamaktadır.

93 İbnu'I-Kayserânî, Ebu'l-Fadl Muhammed b. Tahir, Tezkiretu'I-huffâz Etrafu Ehadis Kitabi'l-Mecruhin li Ibn Hıbbân, Daru's-Semiî, I. bs., Riyad 1994, I, 377 (964).

94 el-Fettenî, Tezkiretu'l-mevdûat, Matbaatu'l-Meymeniyye, I. bs. Mısır, 1343, I, 188.

95 Aliyu'l-Kârî, el-Esrâru'l-merfua fi'l-ahbari'l-mevdûa, thk. Muhammed Sabbağ, Beyrut, Daru'l-emane, ty., I, 186 (172); el-Masnu', I, 94 (111).

96 Aclunî, Keșfu'l-hafâ, I, 357 (1137).

${ }^{97}$ Râzî, Mefâtihu'l-gayb, XXXI, 196; İsmail Hakkı b. Mustafa el-İstanbûlî, Rûhu'l-beyân, Dâru inyai Turâsi'lArabî, Beyrut, ty., I, 269; VI, 385; IX, 232, 500; Aliyu'l-Kârî, Şerhu'ş-şifâ, Daru'I-Kütübi'l-IIImiyye, I. bs., Beyrut 1421, I, 77 (382); böyle bir rivayete hadis eserlerinde rastlamadık. 


\section{3. Şerh Esnasında Farklı Konulara Meyletmesi}

Bu konu hemen hemen bütün sûfî şarihlerde görülen bir durumdur. Onlar bazen şerh ettikleri asıl hadisleri unutmuş ve farklı konulara dalmışlardır. el-Aksarayî de bu çalışmasında şerh esnasında istişhad için getirdiği âyet ve hadislerin şerhine ağırlık verip bazen asıl hadisin kendisinden uzaklaşmıştır. Her ne kadar sona doğru asıl metine dönüş yapsa da bu durum asıl hadisin şerhine izahta yeterli olmamıştır. Sanki asıl hadis unutulmuş ve başka mevzulara girilmiştir. Bunun en bariz örneği 26

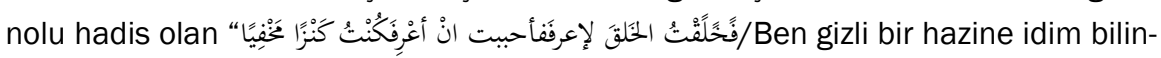

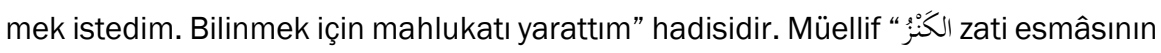
cevherlerine müştemil sırr-ı mahzun'dan ve sıfat esmâsının incisinden bir ibaredir. ise Muhammedî hakikatten ibarettir ki o ervâhın aslıdır/ruhların özüdür" demiş ve buna da "أول ما خلق الله تعالى روحي و أول ما خلق نوري أول ما خلق الله القلم و أول ما خلق الله عقلي Allah Teâlâ önce benim ruhumu ve nurumu yarattı. Allah ilk önce kalemi yarattı, Allah önce benim aklımı yarattı" şeklinde farklı ifadelerle nakledilen kudsî hadisi delil getirdikten sonra esas hadisin konusundan saparak neyin ilk önce yaratıldığı ve neye binaen yaratıldığı konusuna girmiş ve yine konuyla alâkası olmayan “ âyetinin tefsirine girmiştir. Bu konuda diğer bir misâl 15 numaralı hadis olarak verdiği “"يا ابن أدم خلقتك لاجلي وانت تفرُ مني" “Ey Âdemoğlu seni kendim için yarattım sen de benden kaçıyorsun" 99 mealindeki rivayetidir. Burada hem kelimenin anlamından uzaklaşma vardır, hem de esas konudan uzaklaşma söz konusudur. Yorum esna-

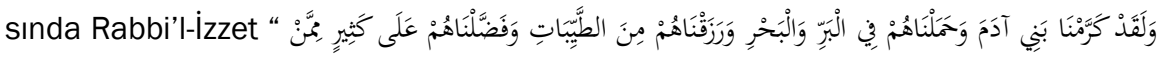

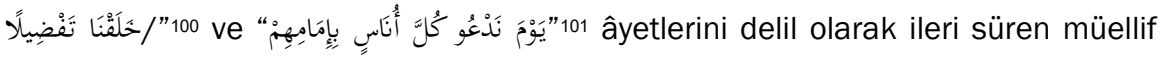
daha sonra bu iki âyet-i kerîmeyi: “Ey akıl sahibi bu âyet-i kerime'nin te'vilini dinle. البر el-Berru'dan maksat, nefis âlemidir. البحر'dan maksat ise kalb âlemidir. البرق'dan

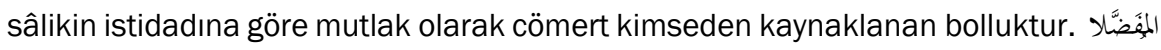

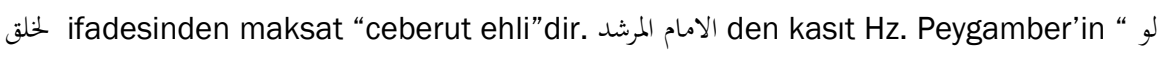
/Şayet mürebbi olmasaydı Rabbimi bilemezdim"102 buyurduğu gibi kâmil, mükemmel olandır" diye açıklar.

el-Aksarayî, söz konusu âyette yer alan اليوم kelimesinden kasıt kulun Allah'ta yok olduktan sonra hakiki hayata gönderildiği gündür. البَر kelimesinden kasıt rubûbiyet

\footnotetext{
98 Sad 38/1.

99 el-Aksarayî, Şerhu erbaîn, Esat Efendi Bölümü nu: 314, 4/b.

100 İsrâ 17/70.

101 İsra 17/71.

102 Böyle bir rivayete ulaşamadık.
} 
ve البَحْر tabirinden maksat ise uluhiyet الرزق ise gizli, saklı ve açık ilimler olabilir" şeklinde zikredilen kelimeleri sembolik bir şekilde yorumlamıştır. ${ }^{103}$

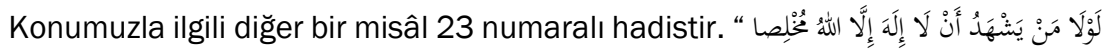
/Şayet hiç bir kimse ihlâslı

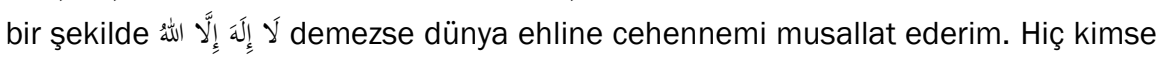
bana ibadet etmezse bana asi olana göz açıp kapayıncaya kadar da olsa mühlet tanırım." mealindeki hadiste görüldüğü gibi konu kulluk ve ihlas üzerine iken müellif "Bilesin ki hakikat-ı Muhammediye hakikatlerin aslıdır. Ondan ortaya çıkan her şey bu hakikatin görüntüsüdür. Habîb-i Rabbi'l-izzet (s.a.v) şu hadisiyle buna işaret eder:

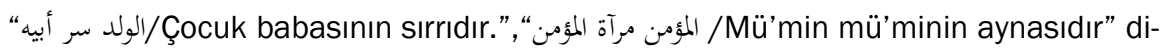
yerek asıl konudan uzaklaşmış olduğu görünmektedir. 104

Konuyla alâkalı çarpıcı bir örnek de şudur: مَنْ قَنَعَ اسْتَفْنَ وَ مَنْ تَرَكَ الحسسد استراح و من تركَ

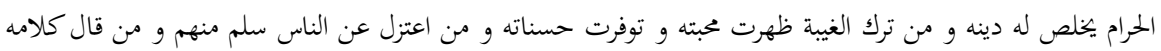
"Kim kanaat ederse zengin olur, kim kıskançlığı terk ederse rahat eder, kim haramı terk ederse dinini korur, kim gıybeti terk ederse ona olan muhabbetim zâhir olur ve güzel işleri çoğalır, kim halktan uzaklaşırsa onlardan güvende olur, kim sözünü söylerse aklı kemale ermiştir, kim rızık konusunda aza razı olursa Allah-ı Teâlâ'nın (azabından) güvende olur."105

Hadisin mealinde açıkça görüldüğü gibi metinde zenginlik, rızık, aza kanaat gibi farklı ahlâki konular işlenmektedir. Ancak müellif öyle bir yoruma girişmiştir ki hem zikrettiği âyetten delillerin hadisin metniyle ilişkisi bulunmamaktadır hem de konunun bütünlüğünden uzaklaşılmış ve farklı mecralara girilmiştir.

Tamamen işârî bir yorum olan bu şerhte müellif bu hadisi kalbin durumlarıyla özdeşleştirmiş, nefs-i mülhimeden Mûsâ - Hızır kısasına geçmiştir. Mezkûr kıssayı şöyle yorumlamaktadır:

Yuşa b. Nûn sultanî akıldır. Ellerindeki kap/zembil kalptir. Balıkları ise gerçek ilimdir ve Mûsâ (a.s.) onu almıştır. Cibrîl, Hakk Subhânehû Teâlâ'nın inayetinin nurudur. Gemi varlık gemisinden alınan nefs-i emmâreyi istemektir. Şükür, aşk makamıdır. Çocuktan maksat talibin nefsidir. Oyun ise süfli maksatlarla alakalı olup bu durum hakk ehline göredir. Çocuğun ölümü ise süfli maksatlarla alâkanın kesilmesidir; çünkü o külli akıldan doğmuştur. Adem ve Havva ve onların çocukları Hâbil ve Kâbil gibi o ikisi de salihlerdendir. Bundan kastım nefs-i emmâre ve nefsi levvâmedir.

103 el-Aksarayî, Şerhu erbaîn, Esat Efendi Bölümü nu: 314, 4/a.

104 el-Aksarayî, Şerhu erbaîn, Esat Efendi Bölümü nu: 314, 6/a.

105 el-Aksarayî, Şerhu erbaîn, Esat Efendi Bölümü nu: 314, 9/a. 
Şit (a.s.) nefs-i mutmainnedir. Sâlikin nefsi, levvâme ve emmâre sıfatlarından mutmainneye geçerse sekinet ve vakar sabit olur. Iki yetim ise kalb ve ruhun çocuğudur. Duvar talibin zatıdır. Köy, talibin vücûdudur. Hazine ise rabbânî hikmet ve Allah'ın esrarıdır. Ilahi esrar/esrâr-ı ilahîye sâlikin keşifleridir. Sâlik keşiflere meyletmiştir. O Allah'ın muhabbetinde ve fena fillah da saklıdır. Keramet ehlinin Allah'tan görünmesini gizlemesini istedikleri söylendiği gibi bundan dolayıdır ki ehli hakk bazı ilahî ilimleri talibin seyr-i sülûkunda tamamlamasına mani olacağı gerekçesiyle saklamışlardır. ${ }^{106}$

\subsection{Diğer Hususlar}

Çalışmamız esnasında ayrıca şu noktalar da dikkatimizi çekmiştir. Bunlar: elAksarayî, sûfî meşrepli yorumlarda pek rastlanmayan Mu'tezile'nin hüsn-kubuh meselesine telminte bulunmaktadır. el-Aksarayî, "Allah şöyle buyurdu; Her kim ki kazama rıza göstermez, belalarıma da sabretmezse artık varsın kendine Benden başka bir Rabb arasın..." 107 mealindeki 20 nolu hadisin şerhinde şu bilgilere yer verir: "Mutlak rubûbiyet özel bir şekilde celâl esmâsı vasıtasıyla, bela ise cemâl esmâsı vasıtasıyla nimetleri cem etmeyi gerektirir. Rabbi'l-izzet sanki şöyle demek istemektedir: "Her kim bu ikisini rubûbiyete dâhil etmezse o vakit layık olmayan bir takım vasıflarla mukayyed/sınırlı, kayıtı Rabb talep etsin. Muhakkak ki Allah Teâlâ bütün vasıfları kendinde toplayandır." O böylece Allah'ın iyi veya kötü her şeyin hâlikı olduğunu söyleyerek Mu'tezile'nin görüşünü tenkit etmektedir.

el-Aksarayî, rivayetleri âyet ve hadislerle desteklemesinin yanı sıra bazen şerhte Arapça veya Farsça şiirlerden de yararlanmaktadır. ${ }^{108}$ Ayrıca müellif eserin tamamında uygun olan her yerde Celâl ve Cemâl isimleri üzerinde durmakta ve müellifin bu iki isim üzerinde sık sık yorumlar yaptığı görülmektedir. ${ }^{109}$

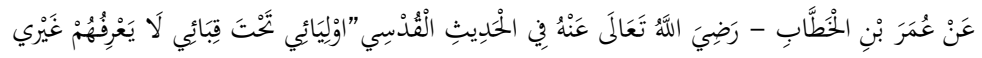

"Velî kullarım benim korumam altındadır/elbisemin altındadır, Benden başkası onları bilemez." 110

O, “Bu hadiste yer alan أولياء kelimesinden maksat kulun nefsinden kurtulup yok olmak için Hakka güvenip ona dayanmasıdır. Yine evliyâdan maksat, Allah'a ulaşmış makbul kimseler de olabilir. القِباب dan maksat nur-ı Celâl ve azamettir ki onu zat-ı ahadiyyenin vergisidir ve herhangi birisi de bunda yer almaz. القباب dan maksat başımızdaki gözle görülmeyen nûr-ı vilâye/vilâyet nurudur. Hadiste yer alan غَيْر nefis, akıl,

\footnotetext{
106 Ayrıca bk. el-Aksarayî, Şerhu erbaîn, Esat Efendi Bölümü nu: 314, 2/b.

107 el-Aksarayî, Şerhu erbaîn, Esat Efendi Bölümü nu: 314, 6/a.

108 el-Aksarayî, Şerhu erbaîn, Esat Efendi Bölümü nu: 314, Hadis nu. 2, 9, 15, 16, 26, 27, 35.

109 el-Aksarayî, Şerhu erbaîn, Esat Efendi Bölümü nu: 314, Hadis nu. 7, 10, 13, 20, 24, 29, 32, 34, 37.

110 el-Aksarayî, Şerhu erbaîn, Esat Efendi Bölümü nu: 314, 10/b, Hadis nu. 37.
} 
kalp ruh da olabilir. لَا يَعْرِفُهُمْ غَيْْ den kastın benden başka hiç bir varlık yoktur da olabilir. O vakit arif ve mâruf tek olur. المعرفة den kasıt, kemal-i marifet de olabilir" diyerek kelimelerin farklı mânalara gelebileceğine dikkat çeker. ${ }^{111}$

Müellifimiz, 9. hadiste ${ }^{112}$ kullandığı şevâhid türünden rivayetin lafız farkıılığına dikkat çekmektedir. Ancak kullanmış olduğu rivayet, hadis değil ỉbn Ebî Revvâd'ın sözüdür. Sehavî’nin kaydettiğine göre bu konuda âlimler şöyle demektedirler: "Fettenî'nin “Bu hadis bilinmez. Ancak Abdulaziz b. Revvâd rüyasında Resûl-i Ekrem'in (s.a.v.) bu şekilde tavsiyede bulunduğunu söyler. Hadisi son kısmı ile birlikte Beyhakî rivayet etmektedir." ${ }^{113}$ Ali el-Kârî de aynı sözü nakletmiştir. ${ }^{114}$ Bunlardan başka Aclûnî eserinde şu bilgilere yer verir: Deylemî zayıf bir senetle merfû olarak Hz. Ali'den rivayet etmektedir. Ali el-Kârî bu rivayeti “ من استوى يوماه فهو مغبون ومن كان يومه شرا من أمسه فهو ملعون. "lafzıyla mevzu hadislere dair telif ettiği kitabında rivayet etmiş ve ibn Ebî Revvad'ın sözü olduğuna dikkat çekmiştir. Irakî de ihyâ'nın tahricinde bunun İbn Ebî Revvâd'ın sözü olduğuna vurgu yapmaktadır."115 Sonuç olarak el-Aksarayî'nin kullanmış olduğu bu rivayet hadis değil, ỉbn Ebî Revvâd'in sözüdür.

\section{SONUÇ}

Sûfîler, Kur'ân ve hadisleri anlama kültürümüze işârî (manevî) yorum yöntemini katarak aşkın boyut eklemişlerdir. Hadislerin zâhirî yorumu dışında, mânevî/rûhânî olarak yorumlamak, özellikle onlara özgün bir tavırdır. Onlar, insanın iç dünyasına, kalbine, gönlüne ve ruhuna hitap etme konusunda diğer İslâm âlimlerinden daha çok başarılı gözükmektedirler. Fıhkî intilaflardan ve salt tartışmalardan uzak durarak âyet ve hadisleri ahlâkî ve manevî açılardan yorumlamaları, onları ahkâm hadislerini bile bu bakış açısından değerlendirmeye sevk etmiştir.

İşârî/manevî yorumun en belirgin özelliği, şerhte hadisi şerh eden âlimin ilmî birikiminin, hâlet-i rûhiyesinin ve kendisinde tecelli eden ilahî mazhariyetlerin tesirinin olmasıdır. Elimizdeki metinde de görüleceği üzere, sûfîlerin yaptıkları yorumların lafızlardan hareketle olduğu ve asıl mânayı bozmamak kaydıyla kelimelere sözlük anlamlarından başka mânalar yükledikleri açıktır. el-Aksarayî örneğinde olduğu gibi bu şerhlerin sıradan bir müslümandan ziyade belli bir olgunluğa erişmiş, tasavvufi bir neşve sahibi insanlara yönelik olduğu görülmektedir. Bu özellikleri olmayan müslüman okuyuculara hitap edip etmediği ve başarısı tartışmalıdır.

Öte yandan özellikle mevzu hadis edebiyatında, tasavvuf ehlinin hadis uydurdukları yönünde yaygın bir kanaat olsa da bu, esasen bu daha çok ilk beş asırdan

111 el-Aksarayî, Şerhu erbaîn, Esat Efendi Bölümü nu: 314, 10/b.

112 el-Aksarayî, Şerhu erbaîn, Esat Efendi Bölümü nu: 314, 4/a.

113 Sehâvî, Mekâsıd, I, 631 (1080).

114 Aliyu'l-Kârî, el-Masnû', I, 174 (311); el-Esrâru'l-merfûa, I, 328 (458).

115 Aclûnî, Keşfu'l-hafâ, II, 233 (2406). 
sonrası için geçerlidir; zira ilk dönem sûfîlerinde telif edilen tasavvufî eserlerde uydurma rivayetler yok denecek kadar azdır. Ayrıca dikkat çekilmesi gereken diğer önemli bir husus, hadis uydurma ile zayıf, çok zayıf ve mevzû rivayetleri tasavvuf ehlinin eserlerinde yer vermeleri başkadır. Birinci kısım kişiyi Allah nezdinde mesul tutarken ikinci kısım ise hadis usulü açısından ehliyet sahibi olmamaya delalet eder.

el-Aksarayî'nin hadis usûlü bağlamında rivayet ettiği hadislerin bazılarının, ki bunların sayısı 15'tir, râvilerini verirken diğerlerinde bunları inmal etmesi, yine iki hadisin dışında hadisin kaynaklarına temas etmemesi câlib-i dikkattir.

el-Aksarayî'nin eseri bir kudsî hadis çalışması olmasına rağmen eserde yer alan ve sahâbî râvîsinin zikredildiği rivayetlerde hemen hadisin metnine girilmekte ve o, ne Peygamber'e (s.a.v.) ne de Allah'a (c.c.) nispet edilmemektedir. Hadis usulünde bu tür rivayetlere mevkûf haber denir. Hâlbuki durum aslında böyle değildir. Niçin böyle davrandığı bilinmemektedir. Müellif 17 . hadisten sonra yer alan rivayetlerde daha önce belirttiğimiz gibi râvîleri zikretmemiş, doğrudan hadislerin başlarına “ قال " عeya “ "عز من قائل الله تعالى" lafızlarını ekleyerek rivayet etmiştir.

Kudsî hadislere dair hadis kaynaklarında pekçok sahih rivayet bulunmasına rağmen o, oldukça problemli rivayetlere de yer vermiştir. Yaşadığı asırda Anadolu coğrafyasında Buhârî ve Müslim'den rivayette bulunması ve buna işaret etmesi kendisinin bu eserlere ulaştığını göstermektedir. Hadisleri bulmada yeni teknolojik imkânlardan yararlanmamıza rağmen, hem kaydettiği kırk hadisin hem de şevâhid olarak kullandığı hadislerin birçoğunun kaynağını tespit edemedik. Kendisinin bu tür rivayetleri hangi kaynaklardan naklettiği belirsizdir. Sıhhati tartışılmakla beraber kullanmış olduğu bazı hadisleri büyük dedelerinden olan Fahruddin er-Râzînin Mefâtihu'l-Gayb isimli tefsirinden aldığı görülmüştür. Müellifin kırk kudsî hadis hakkında yapmış olduğu bu çalışmanın, müellifin yaşadığı zaman diliminde kitlelere ulaŞıp ulaşmadığı bilinmemekle beraber kütüphanelerde farklı nüshalarının bulunması en azından medrese çevrelerinde tanındığına işaret etmektedir.

Üzerinde çalıştığımız kudsî hadis mecmuasının hangi el-Aksarayî'ye ait olduğu tartışmalıdır. Zira bibliyograflar bu konuda farklı bilgiler vermektedirler. Cemâleddin el-Aksarayî'ye atfedilen kırk hadis mecmualarının tam olarak kime ait olduğunun iyi tespit edilmesi gerekmektedir. Biz Muhammed b. Mahmud el-Aksarayî'ye atfedilen Kudsî Hadislere Dair Kırk Hadis Risâlesi'nde takip edilen metodu değerlendirmiş olduk. 


\section{Kaynakça}

» Abdullah b. Ahmed, es-Sünne, thk. Muhammed Saîd Salim el-Kahtânî, Dâru İbni'l-Kayyim, I. Baskı, Dammam 1406.

» Abdurrahman Câmiî, Nefahâtü'l-üns min hadarâti'l-kuds, çev. ve şrh. Lâmiî Çelebi, İstanbul 1980.

» Aclûnî, Keşfu'l-hafâ ve mezîli'l-ilbâs ammâ iştehere mine'l-ehâdis alâ elsineti'n-nâs, Müessesetü'r-risâle, Kahire 1351.

» Ahmed b. Hanbel, Ebû Abdillah eş-Şeybânî, Müsned, thk. Şuayb Arnavud - Adil Mürşid vd, Kontrol: Abdullah b. Abdilmuhsin et-Türkî, Müssesetü'r-risâle, I. Baskı, 2001.

» Ahmed Rıfat Efendi (Yaglıkçızâde), Lügât-ı tarihiyye ve coğrafiyye, Mahmut Bey Matbaası, İstanbul 1299.

» Aksarayî, Şerhu erbaîn, Süleymaniye Kütüphanesi, Esat Efendi Bölümü nu: 314.

» Aliyu'l-Kârî, Ali b. Muhammed, el-Esrâru'l-merfua fi'l-ahbari'l-mevdûa, (Muhammed Sabbâğ), Daru'l-emane, Beyrut ty.

») Ali el-Kârî, Mirkâtul-mefâtih şerhu mişkâtu'l-mesâbîh, Daru'l-fikr, I. Baskı, Beyrut 2002. , el-Masnu' fi ma'rifet'i-hadis el-mevdû', thk. Abdulfettah Ebû Guddde, Mektebetü'l-matbuati'l-i̇slâmiyye, Beyrut 1398.

$\gg$ Şerhu'ş-şifâ, Dâru'l-kütübi'l-ilmiyye, I. Baskı, Beyrut 1421.

» Âlûsî, Şihâbuddin Mahmud b. Abdillah el-Hüseynî, Rûhu'l-meâni fi tefsiri Kur'âni'l-azîm ve seb'i'lmesânî, thk. Ali Abdülbârî Atiyye, Dâru'l-kütübi'l-ilmiyye, I. Baskı, Beyrut 1415.

» Ateş, Süleyman, Işari Tefsir Okulu, Ankara Üniversitesi İlahiyat Fakültesi, Ankara 1974.

» Aynî, Ebû Muhammed Mahmud b. Ahmed, 'Umdetu'l-kârî şerhu Sahîhi'l-Buhârî, Dâru ihyai turâsi'l-Arabî, Beyrut ty.

» Begavî, Ebû Muhammed el-Hüseyin b. Mes‘ud b. Muhammed b. el-Ferrâ, Şerhu's-sünne, thk. Şuayb Arnavud - Muhammed Zuheyr Şaviş, Mektebetü'l-İslâmî, III. Baskı. Dımeşk-Beyrut 1983/1403.

।) Bağdatlı İsmail Paşa, İzâhu'l-meknûn fi'z-zeyl alâ keşfi'z-zunûn an esâmii'l-kütüb ve'l-funûn, Milli Eğitim Bakanlığı, Ankara 1971.

» Beyhakî, Ahmed b. el-Hüseyin b. Ali b. Mûsâ el-Hüsrevverdî el-Horasanî Ebû Bekr, es-Sünenü’kübrâ, thk. Muhammed Abdulkadir Atâ, Mektebetü dârü’l-bâz, III. Baskı, Beyrut 2003/1424.

»_ el-Esmâ ve's-sıfât, thk. Abdullah b. Muhammed el-Hașidî, Matbaatü's-Saade, I. Baskı, Cidde 1993/1413.

» __ el-Kadâ ve'l-kader, thk. Muhammed b. Abdillah Âl-i Âmir, Mektebetü'r-Rüşd, I. Baskı, Riyad 2000/1421.

» _ Şuabu'l-iman, thk. Abdu'l-Ali Abdulhamid Hamid, Mektebetü'r-Rüşd, I. Baskı, Riyad 2003/1423.

» Bezzâr, Ebû Bekr Ahmed b. Amr, Müsned, thk. Adil b. Sa'd, Mektebetu'l-ulûm ve'l-hikem, I. Baskı. Medine 1988.

» Bilmen, Ömer Nasuhi, Büyük Tefsir Tarihi Tabakâtu'I müfessirin, Bilmen Yayınevi, İstanbul 1974.

" Buhârî, Muhammed b. İsmail el-Cu'fi, el-Edebu'l-müfred, thk. Semir b. Emin Zührî, Mektebetu'lMeârif, I. Baskı, Riyad 1998/1419.

»_ el-Câmiu's-sahîh, thk. Muhammed Zuheyr b. Nâsır en-Nâsır, Dâru Tavki'n-Necat, 1422.

Bursalı Mehmet Tahir, Osmanlı Müellifleri, Matba-i Âmire, İstanbul 1333.

Dârekutnî, Ebü'l-Hasen Ali b. Ömer b. Ahmed b. Mehdî, el-ilelu'l-vâride fi ehâdisi'n-nebeviyye, thk. Zemînullah es-Silefi, Dâru Tayyibe, I. Baskı, Riyad 1424/2003.

» Deylemî, Şiruveyh b. Şehredar b. Şiruveyh b. Fenahüsrev, el-Firdevs bi me'suri'l-hitâb, Dâru'l-kütübi'l-ilmiyye, I. Baskı, Beyrut, 1986/1406.

» Ebû Davud, ez-Zühd, thk. Ebû Temim Yâsir b. İbrahim b. Muhammed, Dâru'l-mişkat, I. Baskı, Halvân 1993/1414.

» Ebû Davud, Süleyman b. el-Eşâs, Sünen, thk. Muhammed Muhyiddin Abdilhamid, Dâru'l-fikr, Beyrut ty.

» Ebû Tâlib el-Mekkî, Muhammed b. Ali b. Atiyye, Kût'u'l-kulûb fi muâmeleti'l-mahbûb ve vasfi tariki'l-merîd ila makâmi't-tevhîd, thk. Âsım İbrahim el-Keyâlî, Dâru'l-kütübi'l-ilmiyye, II. Baskı, Beyrut 2005/1426.

» Ebû Ya'la, Ahmed b. Ali b. el-Müsennâ b. Yahya b. Îsâ b. Hilâl et-Temimî el-Mevsılî, Müsnedü Ebi Ya'lâ, thk. Hüseyin Selim Esed, Dâru'l-Memun, I. Baskı, Dımeşk, 1984/1404. 
") Ebu's-Suûd, el-Imadî Muhammed b. Muhammed b. Mustafa, Irşâdu'l-akli's-selîm ilâ mezâyâ'lkitabi'l-kerîm, Beyrut ty.

» Elbanî, Ebû Abdirrahman Muhammed Nâsıruddin, Daîfu'l-câmii's-sağîr ve ziyâdetüh, kontrol. Züheyr Şaviş, Mektebetü'l-İslami, Beyrut 1988.

$\gg$ es-Silsiletu'd-daife ve mevdûa ve eseruha es-seyyie fi'l-ümme, Dâru'l-meârif, I. Baskı, Riyad 1992.

» Fettânî, Tezkiretu'l-mevdûat, Matbaatu'l-meymeniyye, I. Baskı, Mısır 1343.

» Hızlı, Mefail, “Osmanlı Medreselerinde Okutulan Dersler ve Eserler”, Uludağ Üniversitesi Illahiyat Fakültesi Dergisi, Bursa, XVII/1 (2008): 25-46.

» Hindî, Alâuddin Ali b. Hısam, Kenzu'l-ummâl, thk. Saffet Saka - Bekri Hayati, Müessesetü'r-risâle, V. Baskı, Beyrut 1981-1401.

) Humeydî, Müsned, thk. Hasen Selim Esed, I. Baskı, Dımeşk 1996.

» Hüseyin Hüsameddin, Amasya Tarihi, Hikmet Matbaası, I. Baskı, İstanbul 1927.

") Irakî, Ebu'l-Fadı Zeynüddîn Abdurrahîm b. el-Hüseyin, el-Muğnî an hamli'l-esfâr fi'l-esfîr fî tahrîc mâ fí'l-ihyâ mine'l-ahbâr, Daru İbn Hazm, I. Baskı, Lübnan 2005.

» İbn Arabî, el-Fütuhâtü'l-mekkiyye, Dâru'l-Fikr, Beyrut 1994.

» İbn Arrâk, Nureddin Ali b. Muhammed, Tenzîhu'ş-şerîati'l-merfûati ani'l-ahbâri'ş-şenia el-mevdûa, thk. Abdulvehhâb Abdüllatif - Abdullah Muhammed Sıddık Gumarî, Daru'l-Kütübi'l-IImiye, I. Baskı, Beyrut 1399.

» Ibn Ebî Şeybe, Musannef fi'l-ehâdis ve'l-asâr, thk. Kemal Yusuf el-Hût, Mektebetü'r-rüşd, Riyad 1409.

» Ibn Hacer, Fethu'l-bârî şerhu sahîhi'l-Buhârî, tashih. Muhubiddin el-Hatib, numaralama. Fuad Abdulbâkî; talik. Abdulaziz b. Abdillah b. Bâz, Dâru'l-Fikr, Beyrut, 1379.

" İbn Huzeyme, Ebû Bekr Muhammed b. İshak en-Nisâbûrî, Sahîh, Muhammed Mustafa el-Azamî, Mektebetü'l-islâmî, II. Baskı, Beyrut 1992.

» İbn Hıbbân, Muhammed b. Hıbbân el-Bustî, Sahîh, thk. Şuayb el-Arnavud, Müessesetü'r-risâle, I. Baskı, Beyrut, 1988/1408.

» İon Kayyim el-Cevziyye, Muhammed b. Ebî Bekr b. Eyub b. Sa‘d Şemsüddin, Medâricü's-sâlikîn beyne menâzîl iyyâke na'budu ve iyyâke nestaîn, thk. Muhammed Mutasım Billâh, Dâru'l-kitabi'l-Arabi, II. Baskı, Beyrut, 1996/1416.

» İbn Mâce, Ebû Abdillah Muhammed b. Yezîd, Sünen, Muhammed Fuad Abdulbakî, Dâru'l-fikr, Beyrut ty.

» İbn Manzûr, Muhtasar tarihi dımeşk li ibn asâkir, Dımeşk, thk. Heyet, Dâru'l-fikr, I. Baskı, Dımeşk 1984/1402

» İbn Teymiyye, Mecmûu'l-fetâvâ, derleyen. Abdurrahman b. Muhammed b. Kâsım el-Âsımî ve oğlu, Mecmau'l-Melik Fehd litıbâti'l-mushafi'ş-şerif, Medine-i Münevvere, 1995.

» İsfehânî, Ebû Nuaym Ahmed b. Abdillah b. Ahmed, Hilyetu'l-evliyâ ve tabakâtu'l-asfiyâ, Daru'lkitabi'l-Arabi, Mısır, 1974/1394.

» İshak b. Râhuye, Müsned, Abdulgafur b. Abdilhak el-Belûşî, Mektebetü'l-îmân, I. Baskı, Medine-i Münevvere 1991/1412.

') İsmail Hakkı b. Mustafa İstanbulî, Rûhu'l-beyân, Dâru ihyai türâsi'l-Arabî Beyrut, ty.

" Katip Çelebi, Hacı Halife Mustafa b. Abdillah, Keşfu'z-zunûn an esâmi'l-kütüb ve'l-funûn, neşreden. Şerafettin Yaltkaya - Rıfat Bilge, I. Baskı, İstanbul, 1941-1943.

» Kehhâle Ömer Rıza, Mu'cemi'l-müellifîn (Terâcimu musannifi'l-kütübi'l-arabiyye), Daru'l-Kütübi'lİlmiyye, I. Baskı, Beyrut 1957.

» Kettânî, Muhammed b. Ca'fer, er-Risâletü'l-mustatrafe li beyâni meşhuri kütübi's-sitteti'l-müşerrefe (Hadis Literatürü), thk. Yusuf Özbek, İz Yayıncılık, İstanbul 1994.

» Kudâî, Ebû Abdillah Muhammed b. Selâme, Müsnedu'ş-şihâb, Müessetü'r-risâle, II. Baskı, Beyrut 1986.

» Küçükdağ, Yusuf, Il. Bayezid Yavuz ve Kanunî Devirlerinde Cemalî Ailesi, PRS Perek Yayıncılık, İstanbul 1995.

» Leknevî, Ebü'l-Hasanât Muhammed Abdulhayy el-Hindî, el-Ecvibetu'l-fâdıla li'l-es'ileti'l-aşrati'lkâmile, Talik: Abdulfettâh Ebû Gudde, II. Baskı, Kahire 1984.

» Mâlik b. Enes, Muvatta, thk. Fuad Abdülbaki, Dâru inyâi türâsi'l-Arabî, Beyrut 1985/1406.

» Ma‘mer b. Raşid, el-Câmi’, thk. Habîbu'r-Rahmân Azamî, el-Mektebü'l-íslamî, II. Baskı, Beyrut 1403. 
» Mehmed Süreyya, Sicill-i Osmanî yahut Tezkire-i Meşâhir-i Osmaniyye, (The Ottoman Biography), I. Baskı, İstanbul 1971.

» Muhammed b. Muhammed Derviş Ebû Abdirrahman el-Hût, Esne'I-metâlib fî ehâdisi muhtelifeti'lmerâtib, thk. Mustafa Abdulkadir Atâ, Mektebetü'r-Rüşd, I. Baskı, Beyrut 1997/1418.

» Münâvî, Abdurraûf, et-Tevkıf ala muhimmati't-teârif, Daru'l-Fikr, I. Baskı, Kahire 1990/1410.

» Münâvî, et-Teysîr bi-şerhi'l-Câmii's-sağîr, Mektebetü İmam eş-Şâfiî, III. Baskı, Riyad 1988.

» Müslim b. el-Haccâc el-Kuşeyrî en-Nisâbûrî, Sahîh, thk. Muhammed Fuad Abdilbakî, Daru ihyâi’ttürâsi'l-Arabi, Beyrut ty.

» Nesâî, Ebû Abdirrahman Ahmed b. Şuayb, Sünen, thk. Abdulfettah Ebû Gudde, Mektebetü'l-matbuati'l-İslâmiyye, Haleb, 1986/1406.

» Öngören Reşat, Osmanlılarda Tasavvuf Anadolu'da Sûfîler, Devlet ve Ulema (XVI Yüzyıl), İz Yayıncllık, 1. Baskı, İstanbul 2000.

» Öz, Mustafa, "Cemaleddin el-Aksarayî”, Diyanet Vakfı İslam Ansiklopedisi, İstanbul 1993, VII, 308-309.

» Razî, Fahruddin Ebû Abdillah Muhammed b. Ömer b. el-Hasen, Mefâtihu'l-gayb, Daru'l-kütübi'lilmiyye, III. Baskı, Beyrut 1420.

» Sa'lebî, Ebû Zeyd Abdurrahman b. Muhammed b. Mahlûf, el-Cevâhiru'l-hisân fî tefsiri'l-Kur'ân, thk. Muhammed Ali Muavvid - Adil Ahmed Abdülmevcud, Dâru ihyâ-i türâasi'l-Arabî, I. Baskı, Beyrut 1418

» Sehâvî, el-Mekâsıdu'l-hasene fi beyâni kesîrin mine'l-ehâdisi'l-müştehire ale'l-elsine, thk. Muhammed Osman el-Hıst, Dâru'l-kütübi'l-Arabiyye, I. Baskı, Beyrut 1985

» Suyûtî, el-Fethu'l-kebîr fí dammi'z-ziyâde ile cezmi's-sağîr, thk. Yusuf Nebhanî, Dâru'l-fikr, I. Baskı, Beyrut 2003/1423.

" __ el-Leâli'l-masnûa fi'l-ehâdis'l-mevdûa, thk. Ebû Abdirrahman Salâh b. Muhammed b. Uveyda, Daru'I-kütübi'l-ilmiyye, I. Baskı, Beyrut 1996/1417.

» Sülemî, Ebû Abdirrahman, Tabakâtu's-sûfiyye, Mustafa Abdulkadir Atâ, I. Baskı, Beyrut, $1998 / 1419$.

» Şahin, İlhan, “Aksaray”, Türkiye Diyanet Vakfı İslam Ansiklopedisi, İstanbul 1989, II, 291-292.

» Şaşî, Ebû Saîd el-Heysem b. Kuleyb b. Sureyc b. Ma'kıl, Müsned, thk. Mahfuzurrahman Zeynullah, Mektebetü'l-ulûm, I. Baskı, Medine-i Münevvere 1410.

» Şevkânî, el-Fevâidu'l-mecmûa, Mabaatu es-Sünnetu'l-Muhammediyye, I. Baskı, Kahire, 1960.

» Taberânî, el-Mu'cemu'l-kebîr, thk. Hamdî b. Abdilmecid es-Silefî, Mektebetü'l-Ulum, II. Baskı, Kahire ty.

"___ el-Mu'cemu'l-evsat, thk. Tarık b. Ivadillah - Abdulmuhsin b. İbrahim, Daru'l-Harameyn, Kahir ty.

» Taberî, Süleyman b. Ahmed, ed-Duâ, thk. Mustafa Abdulkadir Atâ, Dâru'l-kütübi'l-ilmiyye, I. Baskı, Beyrut 1413.

» Tahâvî, Ebû Ca'fer Ahmed b. Muhammed b. Selame el-Ezdî el-Mısrî, Şerhu müşkilu'l-asâr, thk. Şuayb Arnavud, Müessesetü'r-Risâle, I. Baskı, Beyrut 1415.

» Taşköprüzade Ebü'l-Hayr İsâmuddin Ahmed Efendi, eş-Şekâikun-numâniye fi ulemâi'd-devleti'lOsmâniyye, thk. Ahmet Sübhi Furat, İstanbul Üniversitesi Edebiyat Fakültesi Basımevi, I. Baskı, İstanbul 1985.

» Tayşi, Mehmed Serhan, "Cemâl-î Halvetî", Türkiye Diyanet Vakfı İslam Ansiklopedisi, İstanbul 1993, VII, 302-303.

» Tirmizî, Muhammed b. Îsâ b. Sevre, Sünen, thk. İbrahim Atve, Matbaatu el-Bâb el-Halebî, I. Baskı, Mısır 1975/1395.

» Uzunçarşılı, İsmail Hakkı, Büyük Osmanlı Tarihi, Türk Tarih Kurumu Yayınları, I. Baskı, Ankara yy.

") Yusuf b. Yakub, Menâkıbı şerif ve tarikatnâme-i piran ve meşâyihi tarikat-ı aliye-i halvetiyye, İstanbul 1290.

» Zirikli, Hayreddin, el-A‘lâm: Kâmûsu terâcimi li eşheri'r-ricâl ve'n-nisâ, Kahire 1976.

» Zurkânî, Muhammed b. Abdulbaki, Şerhu'z-Zurkânî ale'I-Muvatta, Dâru'l-kütübi'l-ilmiye, I. Baskı, Kahire 2003/1424. 